\title{
Origin of aerosol particles in the mid-latitude and subtropical upper troposphere and lowermost stratosphere from cluster analysis of CARIBIC data
}

\author{
M. Köppe ${ }^{1}$, M. Hermann ${ }^{1}$, C. A. M. Brenninkmeijer ${ }^{2}$, J. Heintzenberg ${ }^{1}$, H. Schlager ${ }^{3}$, T. Schuck ${ }^{2}$, F. Slemr ${ }^{2}$, \\ D. Sprung ${ }^{4,2}$, P. F. J. van Velthoven ${ }^{5}$, A. Wiedensohler ${ }^{1}$, A. Zahn ${ }^{4}$, and H. Ziereis ${ }^{3}$ \\ ${ }^{1}$ Leibniz Institute for Tropospheric Research, Permoserstr. 15, 04318 Leipzig, Germany \\ ${ }^{2}$ Atmospheric Chemistry Division, Max Planck Institute for Chemistry, P.O. Box 3060, 55020 Mainz, Germany \\ ${ }^{3}$ Institute of Atmospheric Physics, German Aerospace Center, Oberpfaffenhofen, 82230 Wessling, Germany \\ ${ }^{4}$ Institute for Meteorology and Climate Research, Karlsruhe Institute of Technology, P.O. Box 3640, \\ 76021 Karlsruhe, Germany \\ ${ }^{5}$ Royal Netherlands Meteorological Institute, P.O. Box 201, 3730 AE de Bilt, The Netherlands
}

Received: 25 May 2009 - Published in Atmos. Chem. Phys. Discuss.: 18 June 2009

Revised: 25 September 2009 - Accepted: 7 October 2009 - Published: 5 November 2009

\begin{abstract}
The origin of aerosol particles in the upper troposphere and lowermost stratosphere over the Eurasian continent was investigated by applying cluster analysis methods to in situ measured data. Number concentrations of submicrometer aerosol particles and trace gas mixing ratios derived by the CARIBIC (Civil Aircraft for Regular Investigation of the Atmosphere Based on an Instrument Container) measurement system on flights between Germany and South-East Asia were used for this analysis. Four cluster analysis methods were applied to a test data set and their capability of separating the data points into scientifically reasonable clusters was assessed. The best method was applied to seasonal data subsets for summer and winter resulting in five cluster or air mass types: stratosphere, tropopause, free troposphere, high clouds, and boundary layer influenced. Other source clusters, like aircraft emissions could not be resolved in the present data set with the used methods. While the cluster separation works satisfactory well for the summer data, in winter interpretation is more difficult, which is attributed to either different vertical transport pathways or different chemical lifetimes in both seasons. The geographical distribution of the clusters together with histograms for nucleation and Aitken mode particles within each cluster are presented. Aitken mode particle number concentrations show a clear vertical gradient with the lowest values in the lowermost stratosphere
\end{abstract}

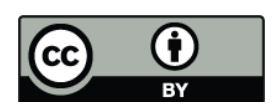

Correspondence to: M. Hermann (hermann@tropos.de)
(750-2820 particles $/ \mathrm{cm}^{3}$ STP, minimum of the two $25 \%$ and maximum of the two $75 \%$-percentiles of both seasons) and the highest values for the boundary-layer-influenced air (4290-22 760 particles/ $\mathrm{cm}^{3}$ STP). Nucleation mode particles are also highest in the boundary-layer-influenced air (126029500 particles $/ \mathrm{cm}^{3} \mathrm{STP}$ ), but are lowest in the free troposphere $\left(0-450\right.$ particles $\left./ \mathrm{cm}^{3} \mathrm{STP}\right)$. The given submicrometer particle number concentrations represent the first large-scale seasonal data sets for the upper troposphere and lowermost stratosphere over the Eurasian continent.

\section{Introduction}

The implementation of aerosols in global atmospheric models still represents one of the largest uncertainties in assessments of climate change (IPCC, 2007). The complexity of realistically simulating aerosol is obviously due to the large number of relevant physical and chemical particle properties, the great variety of aerosol processes, and the variability of the spatiotemporal distribution of atmospheric aerosol particles (Textor et al., 2007). The need to improve knowledge of atmospheric aerosol properties pertains to their impact on atmospheric chemistry (Seinfeld and Pandis, 2006) and on radiative forcing (Lohmann and Feichter, 2005; IPCC, 2007; Heintzenberg and Charlson, 2009). This holds true in particular for aerosol particles in the upper troposphere/lowermost stratosphere (UT/LMS) region, where they influence cirrus

Published by Copernicus Publications on behalf of the European Geosciences Union. 
clouds and hence the radiation budget of the atmosphere (Kärcher, 2003; Heintzenberg and Charlson, 2009). Furthermore these particles change the chemical composition of the UT/LMS by heterogeneous chemical processes (e.g. Bell et al., 2005; Søvde et al., 2007). Progress in understanding aerosol properties throughout the troposphere is strongly hindered by the technical challenges of airborne measurements and the associated high costs, both leading to a lack of reliable data sets. Fortunately new active satellite instruments, like CALIPSO (http://www-calipso.larc.nasa.gov), close this gap partly, by providing global maps of aerosol properties (e.g. Liu et al., 2008). However, these measurements are always restricted to the optically active particles (larger than $\sim 100 \mathrm{~nm}$ ) and a source attribution is not always possible because co-located trace gas information is lacking.

For a better representation of atmospheric aerosol particles (or trace gases), e.g. in three-dimensional atmospheric models, in situ long-term measurements in the free troposphere are essential (Kunz et al., 2008). Within the CARIBIC project (Civil Aircraft for Regular Investigation of the Atmosphere Based on an Instrument Container; Brenninkmeijer et al., 1999, 2007; http://www.caribic-atmospheric.com), longterm measurements of aerosol particle and trace gas concentrations in the UT/LMS were realized on a monthly basis since 1997. Using an instrumented container on a passenger aircraft (first a Boeing B767 of LTU International Airways and later an Airbus A340-600 of Lufthansa AG) over 220 successful measurement flights were conducted until December 2008. The geographic region covered on mainly five flight routes spans from northern mid-latitudes to southern subtropics (http://www.caribic-atmospheric.com). Accordingly, the CARIBIC project helps to close some of the observational gaps by yielding a large-area data set, which can help to validate atmospheric models (Kim et al., 2008) or to verify satellite based remote sensing instruments (Peylin et al., 2007).

In this study we present and analyze CARIBIC data from flights between Germany and South-East Asia. By using multivariate statistical analysis methods (mainly cluster analysis), we tried to identify types of air masses and hence the origins of sub-micrometer aerosol particles in the UT/LMS. This approach is highly experimental, because the sequence of analysis steps is not known a priori and the results can be hard to interpret (Backhaus et al., 2006). It was chosen, however, because of the large number of variables and data points in the CARIBIC data set. In addition to published methods of statistical analyses for similar data sets (Borchi and Marenco, 2002; Borchi et al., 2005), new combinations of multivariate analysis methods were applied and the results of the various methods are compared.

Section 2 begins with a short description of the aircraft measurements and the data set. The theory of univariate and multivariate statistical analyses and in particular the new method of analysis is presented in Sect. 3. In Sect. 4 the results are discussed and they are summarized in Sect. 5.

\section{Experimental and data set}

The core of the CARIBIC project is the monthly operation of a modified airfreight-container equipped with fully automated in situ measuring instruments and sampling devices for trace gases and aerosol particles. For detailed information about CARIBIC, such as the inlet and the measurement system, we refer to Brenninkmeijer et al. (1999, 2007), references therein, and the CARIBIC website http: //www.caribic-atmospheric.com. The aerosol measurement techniques are explained in more detail by Hermann and Wiedensohler (2001), Papaspiropoulos et al. (2002), Hermann et al. (2003), and Nguyen et al. (2006, 2007).

For analysis, the in situ measured, quality-checked data were combined with aircraft flight parameters and meteorological information (provided by the Koninklijk Nederlands Meteorologisch Instituut, KNMI, de Bilt, the Netherlands, http://www.knmi.nl/samenw/campaign_support/CARIBIC) to so-called "meteo-merged-files". Exemplary parameters in these files are: Trace gas mixing ratios of carbon monoxide $(\mathrm{CO})$, ozone $\left(\mathrm{O}_{3}\right)$, and acetonitrile $\left(\mathrm{CH}_{3} \mathrm{CN}\right)$; number concentrations of aerosol particles between 4 and $12 \mathrm{~nm}$ diameter (nucleation mode, $\mathrm{N}_{4-12}$ ) as well as particles larger than $12 \mathrm{~nm}$ diameter (Aitken mode, $\mathrm{N}_{12}$ ); aircraft pressurealtitude and position; as well as model-derived potential vorticity (PV). Table 1 gives a list of all 52 parameters. In composing the meteo-merged-files, all parameters were averaged over $10 \mathrm{~s}$ intervals, centered at coordinated universal times (UTC) ending with five seconds, i.e. "hh:mm:s5". In order to have more complete data points, for this study the mixing ratios of the two trace gases acetone $\left(\mathrm{CH}_{3} \mathrm{COCH}_{3}\right)$ and acetonitrile, which were obtained with a time resolution of $60 \mathrm{~s}$, were linearly interpolated when the gap between following data points was smaller than $121 \mathrm{~s}$.

Unfortunately, in the data set there are many missing values for individual parameters, caused by instrument malfunctioning or calibration periods. Eventually the data set was reduced strongly by having to eliminate all data points from multivariate statistical analyses affected by missing values for individual parameters. For summer and winter seasons, defined below, only $26 \%$ and $38 \%$, respectively, of the original data points could be used. The missing values occur mainly in the data of the three trace gases $\mathrm{CH}_{3} \mathrm{CN}$, $\mathrm{CH}_{3} \mathrm{COCH}_{3}$, and $\mathrm{NO}_{\mathrm{y}}$, i.e. in the data of two instruments. For these instruments between $40 \%$ and $70 \%$ of the missing values are caused by regular instrument calibration, which should not influence the results of the data analysis. Instrument malfunctioning is responsible for the rest of the missing values of the two instruments.

In order to be sure that the data reduction does not influence the following multivariate analysis, we compared histograms of the original data set and the reduced data set with respect to e.g. the geographical distribution, altitude, or the local time of day. Besides the geographical distribution of data points for summer, which shows a larger fraction 
Table 1. Parameters in the CARIBIC meteo-merged-files. "mr" stands for mixing ratio and the md for model-derived parameters. Bold parameters were used for the multivariate statistical analyses methods in this study.

\begin{tabular}{|c|c|c|c|}
\hline Parameter & Unit & Parameter & Unit \\
\hline $\begin{array}{l}\text { PCUTC } \\
\text { (container master computer) }\end{array}$ & $\begin{array}{l}\text { days since } 1 \text { January } 1900 \\
\text { and time in fraction of day }\end{array}$ & Liquid water $\left(\mathrm{H}_{2} \mathbf{O}_{\text {cloud }}\right) \mathrm{mr}$ & ppmv \\
\hline $\begin{array}{l}\text { UTC ARINC Julian time } \\
\text { (aircraft) }\end{array}$ & $\begin{array}{l}\text { days since } 1 \text { January } 1900 \\
\text { and time in fraction of day }\end{array}$ & Ozone $\left(\mathbf{O}_{3}\right) \mathrm{mr}$ & ppbv \\
\hline Flight phase & $0-10$, e.g., $4=$ take off & Nitric oxide (NO) mr & ppbv \\
\hline Position latitude & $\circ$ & Reactive nitrogen $\left(\mathrm{NO}_{\mathrm{y}}\right) \mathrm{mr}$ & ppbv \\
\hline Position longitude & $\circ$ & CARIBIC Master PC time & s \\
\hline True Heading & $\circ$ & Carbon monoxide $(\mathrm{CO}) \mathrm{mr}$ & ppbv \\
\hline Wind speed & $\mathrm{kn}$ & $\begin{array}{l}\text { Concentration of particles } \\
\text { between } 4 \text { and } 12 \mathrm{~nm}\left(\mathbf{N}_{\mathbf{4}-12}\right)\end{array}$ & particles $/ \mathrm{cm}^{3} \mathrm{STP}$ \\
\hline Wind direction & $\circ$ & $\begin{array}{l}\text { Concentration of particles } \\
\text { larger than } 12 \mathrm{~nm}\left(\mathrm{~N}_{12}\right)\end{array}$ & particles $/ \mathrm{cm}^{3} \mathrm{STP}$ \\
\hline Pitch angle & $\circ$ & $\begin{array}{l}\text { Concentration of particles } \\
\text { larger than } 18 \mathrm{~nm}\left(\mathrm{~N}_{18}\right)\end{array}$ & particles $/ \mathrm{cm}^{3} \mathrm{STP}$ \\
\hline Roll angle & $\circ$ & Acetonitrile $\left(\mathrm{CH}_{3} \mathrm{CN}\right) \mathrm{mr}$ & pptv \\
\hline Altitude & feet & Acetone $\left(\mathrm{CH}_{3} \mathrm{COCH}_{3}\right) \mathrm{mr}$ & pptv \\
\hline Barro-corrected altitude & feet & Static temperature $\mathrm{md}$ & $\mathrm{K}$ \\
\hline True airspeed & $\mathrm{kn}$ & Potential vorticity $(\mathbf{P V})^{\mathrm{md}}$ & PVU \\
\hline Total air temperature & ${ }^{\circ} \mathrm{C}$ & Potential temperature ${ }^{\mathrm{md}}$ & $\mathrm{K}$ \\
\hline Altitude rate & feet $/ \mathrm{min}$ & $\begin{array}{l}\text { Equivalent potential } \\
\text { temperature }^{\text {md }}\end{array}$ & $\mathrm{K}$ \\
\hline Static air temperature & ${ }^{\circ} \mathrm{C}$ & Amount of water vapor ${ }^{\mathrm{md}}$ & $\mathrm{kg} / \mathrm{kg}$ \\
\hline Corrected angle of attack & $\circ$ & Eastward wind ${ }^{\mathrm{md}}$ & $\mathrm{m} / \mathrm{s}$ \\
\hline Total pressure & mbar & Northward wind ${ }^{\text {md }}$ & $\mathrm{m} / \mathrm{s}$ \\
\hline Vertical velocity & feet/min & Vertical wind speed $^{\text {md }}$ & $\mathrm{Pa} / \mathrm{s}$ \\
\hline Ground speed & $\mathrm{kn}$ & Wind speed ${ }^{\mathrm{md}}$ & $\mathrm{m} / \mathrm{s}$ \\
\hline Local time & Julian time & Wind direction ${ }^{\mathrm{md}}$ & $\circ$ \\
\hline Static pressure & mbar & Total amount of water ${ }^{\mathrm{md}}$ & ppmv \\
\hline Potential temperature & $\mathrm{K}$ & Relative humiditymd & $\%$ \\
\hline Altitude & $\mathrm{m}$ & Cell cloud cover ${ }^{\mathrm{md}}$ & 0 to 1 \\
\hline Status & sensor work, 0-3 & Cloud water content ${ }^{\text {md }}$ & $\mathrm{kg} / \mathrm{m}^{3}$ \\
\hline Gaseous water $\left(\mathbf{H}_{2} \mathbf{O}_{\text {gas }}\right) \mathrm{mr}$ & ppmv & Cloud ice content $^{\mathrm{md}}$ & $\mathrm{kg} / \mathrm{m}^{3}$ \\
\hline
\end{tabular}

of data points for the longitudes $20-50^{\circ} \mathrm{E}$ and $100-110^{\circ} \mathrm{E}$, and a smaller fraction in the region $60-80^{\circ} \mathrm{E}$ compared to the original data set, all compared histograms look similar, which gives some confidence that the reduced data set is not strongly biased.

Before applying the multivariate statistical analysis methods to the meteo-merged-files, the data set was reduced in order to keep computing burden within reasonable limits. In this reduction step those variables that are a priori irrelevant for determining the particle origin, such as the aircraft flight parameters "pitch angle" or "roll angle", were eliminated. Consequently, the CARIBIC data subset used in this study consists of 25 essential parameters, which are called "original variables" hereafter (printed bold in Table 1).

For the air-mass-based assessment of submicrometer aerosol particle types in the UT/LMS, we primarily use specific trace gases as indicators (tracers) for the origin of respective air masses. In particular, $\mathrm{O}_{3}, \mathrm{CO}$, and $\mathrm{CH}_{3} \mathrm{CN}$ are relevant and can be used as indicators of stratospheric air (e.g. Zahn and Brenninkmeijer, 2003), boundary layer air (e.g. Zahn et al., 2002; Hoor et al., 2005), and biomassburning-influenced air (de Gouw et al., 2003, 2006), respectively.

Some of these essential tracers were available in sufficient degree only for the CARIBIC flights since 2006, which predominantly cover the South-East Asia route. Consequently, we exclusively used the CARIBIC data obtained on longdistance flights from Frankfurt (Germany) to Manila (Philippines) and back. Each flight consisted of two legs with a brief stopover in Guangzhou (China). The actual flight tracks of the flights used in this study are displayed in Fig. 1. They cover an area from Eastern Europe (mid-latitudes, $\sim 50^{\circ} \mathrm{N}$, 
Table 2. Seasonal assignment of the flights to the summer-, winter-, and test data set. Each flight leg of the monthly flights obtained its individual number. Missing numbers indicate flights conducted on alternative routes. Flights assigned to the summer data set are highlighted by red, flights of winter data set by blue, and flights not assigned to either one of them by grey color. Flights of the test data set are indicated by a "T", flights with no data (e.g. no power to the container) by "n.a.". Airports codes are Frankfurt (FRA), Guangzhou (CAN), and Manila (MNL).

\begin{tabular}{|c|c|c|c|c|c|c|c|}
\hline Number & Direction & Date & Note & Number & Direction & Date & Note \\
\hline 146 & FRA-CAN & 27 Apr 2006 & $\mathrm{~T}$ & 104 & MNL-CAN & 7 Mar 2007 & \\
\hline 147 & CAN-MNL & 28 Apr 2006 & $\mathrm{~T}$ & 185 & CAN-FRA & 7 Mar 2007 & \\
\hline 148 & MNL-CAN & 28 Apr 2006 & $\mathrm{~T}$ & 186 & FRA-CAN & 18 Apr 2007 & \\
\hline 149 & CAN-FRA & 28 Apr 2006 & $\mathrm{~T}$ & 187 & CAN-MNL & 19 Apr 2007 & \\
\hline 150 & FRA-CAN & 29 May 2006 & $\mathrm{~T}$ & 188 & MNL-CAN & 19 Apr 2007 & \\
\hline 151 & CAN-MNL & 30 May 2006 & $\mathrm{~T}$ & 189 & CAN-FRA & 19 Apr 2007 & \\
\hline 152 & MNL-CAN & 30 May 2006 & $\mathrm{~T}$ & 190 & FRA-CAN & 22 May 2007 & \\
\hline 153 & CAN-FRA & 30 May 2006 & $\mathrm{~T}$ & 191 & CAN-MNL & 23 May 2007 & \\
\hline 154 & FRA-CAN & 5 Jul 2006 & $\mathrm{~T}$ & 192 & MNL-CAN & 23 May 2007 & \\
\hline 155 & CAN-MNL & 6 Jul 2006 & $\mathrm{~T}$ & 193 & CAN-FRA & 23 May 2007 & \\
\hline 156 & MNL-CAN & 6 Jul 2006 & $\mathrm{~T}$ & 194 & FRA-CAN & 21 Jun 2007 & \\
\hline 157 & CAN-FRA & 6 Jul 2006 & $\mathrm{~T}$ & 195 & CAN-MNL & 22 Jun 2007 & \\
\hline 158 & FRA-CAN & $31 \mathrm{Jul} 2006$ & $\mathrm{~T}$ & 196 & MNL-CAN & 22 Jun 2007 & \\
\hline 159 & CAN-MNL & 1 Aug 2006 & $\mathrm{~T}$ & 197 & CAN-FRA & 22 Jun 2007 & \\
\hline 160 & MNL-CAN & 1 Aug 2006 & $\mathrm{~T}$ & 198 & FRA-CAN & 17 Jul 2007 & \\
\hline 161 & CAN-FRA & 1 Aug 2006 & $\mathrm{~T}$ & 199 & CAN-MNL & 18 Jul 2007 & \\
\hline 162 & FRA-CAN & 7 Sep 2006 & $\mathrm{~T}$ & 200 & MNL-CAN & $18 \mathrm{Jul} 2007$ & n.a. \\
\hline 163 & CAN-MNL & 8 Sep 2006 & $\mathrm{~T}$ & 201 & CAN-FRA & $18 \mathrm{Jul} 2007$ & n.a. \\
\hline 164 & MNL-CAN & 8 Sep 2006 & $\mathrm{~T}$ & 202 & FRA-CAN & 14 Aug 2007 & \\
\hline 165 & CAN-FRA & 8 Sep 2006 & $\mathrm{~T}$ & 203 & CAN-MNL & 15 Aug 2007 & \\
\hline 166 & FRA-CAN & 19 Oct 2006 & & 204 & MNL-CAN & 15 Aug 2007 & \\
\hline 167 & CAN-MNL & 20 Oct 2006 & & 205 & CAN-FRA & 15 Aug 2007 & \\
\hline 168 & MNL-CAN & 20 Oct 2006 & & 210 & FRA-CAN & 24 Oct 2007 & \\
\hline 169 & CAN-FRA & 20 Oct 2006 & & 211 & CAN-MNL & 25 Oct 2007 & \\
\hline 170 & FRA-CAN & 14 Nov 2006 & & 212 & MNL-CAN & 25 Oct 2007 & \\
\hline 171 & CAN-MNL & 15 Nov 2006 & & 213 & CAN-FRA & 25 Oct 2007 & \\
\hline 172 & MNL-CAN & 15 Nov 2006 & & 214 & FRA-CAN & 13 Nov 2007 & \\
\hline 173 & CAN-FRA & 15 Nov 2006 & & 215 & CAN-MNL & 14 Nov 2007 & \\
\hline 174 & FRA-CAN & 13 Dec 2006 & & 216 & MNL-CAN & 14 Nov 2007 & \\
\hline 175 & CAN-MNL & 14 Dec 2006 & & 217 & CAN-FRA & 14 Nov 2007 & n.a. \\
\hline 176 & MNL-CAN & 14 Dec 2006 & & 220 & FRA-CAN & 25 Feb 2008 & \\
\hline 177 & CAN-FRA & 14 Dec 2006 & & 221 & CAN-MNL & 26 Feb 2007 & \\
\hline 178 & FRA-CAN & 5 Feb 2007 & & 222 & MNL-CAN & 26 Feb 2008 & \\
\hline 179 & CAN-MNL & 6 Feb 2007 & & 223 & CAN-FRA & 26 Feb 2008 & \\
\hline 180 & MNL-CAN & 6 Feb 2007 & & 224 & FRA-CAN & $26 \operatorname{Mar} 2008$ & \\
\hline 181 & CAN-FRA & 6 Feb 2007 & & 225 & CAN-MNL & 27 Mar 2008 & \\
\hline 182 & FRA-CAN & 6 Mar 2007 & & 226 & MNL-CAN & 27 Mar 2008 & \\
\hline 183 & CAN-MNL & 7 Mar 2007 & & 227 & CAN-FRA & 27 Mar 2008 & \\
\hline
\end{tabular}

$\sim 10^{\circ} \mathrm{E}$ ) via Central and East Asia to South-East-Asia (tropics, $\sim 15^{\circ} \mathrm{N}, \sim 120^{\circ} \mathrm{E}$ ). On this flight route, the actual flight tracks were mainly determined by geography and at least for the Asian part mostly fall into a relative narrow flight corridor (in contrast to e.g. the North-America flight route). Hence we assume no strong bias towards specific synoptic conditions, as it might be expected for commercial aircraft. The final data set consists of 36 long-distance flights, conducted between April 2006 and March 2008 (cf. Table 2). Finally, data are restricted to cruise altitudes between $\sim 8$ and $\sim 12 \mathrm{~km}$ altitude ( $\sim 335$ to $\sim 200 \mathrm{hPa}$ pressure).

Previous studies have already shown that the concentrations of submicrometer aerosol particles undergo strong geographical and seasonal variations (e.g. Hermann et al., 2003). Therefore, a summer (15 flights) and a winter data set (17 flights) were extracted from the available data set. Because of the limited number of flights, each corresponding to only one specific meteorological situation in an overflown 
region, a finer division, e.g., into four seasons was statistically not reasonable. For the division not only the time of the year, but also the synoptic weather situation in the sampling area was considered. Firstly, flights in June, July, and August were assigned to boreal summer and those in December, January, and February to boreal winter. In order to get better statistics, we expand the summer and winter seasons by adding flights from spring and autumn, if the synoptic weather conditions for the flight date showed similar patterns like in summer or winter, respectively. Therefore we checked the synoptic meteorological situation indicated by the positions of controlling anticyclones, cyclones, and frontal zones of general flow patterns (Liljequist and Cehak, 1994; Gerstengarbe et al., 1999a; Malberg, 1997), by pressure level maps (http://www.wetterzentrale.de; http://www. arl.noaa.gov), and by model-derived vertical cross sections of the atmosphere (http://www.knmi.nl/samenw/campaign support/CARIBIC). The four April flights were not assigned, because the synoptic meteorological situation was ambiguous. Most of the data points are located within a corridor of $\sim 1500 \mathrm{~km}$ width (Fig. 1), within the scale of synopticscale systems. Therefore existing differences in flight routes between summer and winter should play a minor role compared to the shift in atmospheric circulation associated with the seasons.

Interpreting the present data sets, one should be aware that because of the fixed flight schedule of commercial aircraft and the mainly east-west flight route the data sets are biased towards certain local times of day (LT). In the winter data set, where this effect is stronger compared to the summer data set, $57 \%$ of the data points were measured in the six hours between 00:00 and 06:00 LT. On the other hand there is a minimum between 15:00 and 21:00 LT, representing only $6 \%$ of the data points. Measurements at mid-latitudes, between $40^{\circ} \mathrm{N}$ and $55^{\circ} \mathrm{N}$, are about $80 \%$ night time measurements. The same holds true for data points below $23^{\circ} \mathrm{N}$, which are about $70 \%$ night time measurements.

For testing and verification of the multivariate statistical methodology (cf. Sect. 3) with reduced computing burden, first a smaller test data set was generated from the summer data set (cf. Table 2).

\section{Statistical methods}

In general, statistical analysis methods can be divided into univariate and multivariate methods by the number of simultaneously investigated variables. While univariate methods readily yield results and hence are suited to give an overview of the data set, multivariate methods are more complex, but also provide deeper insight. Multivariate statistical analyses have been used in atmospheric research for example to investigate the relation between synoptic weather patterns and precipitation chemistry (Dorling and Davies, 1995), the classification of European climates (Gerstengarbe

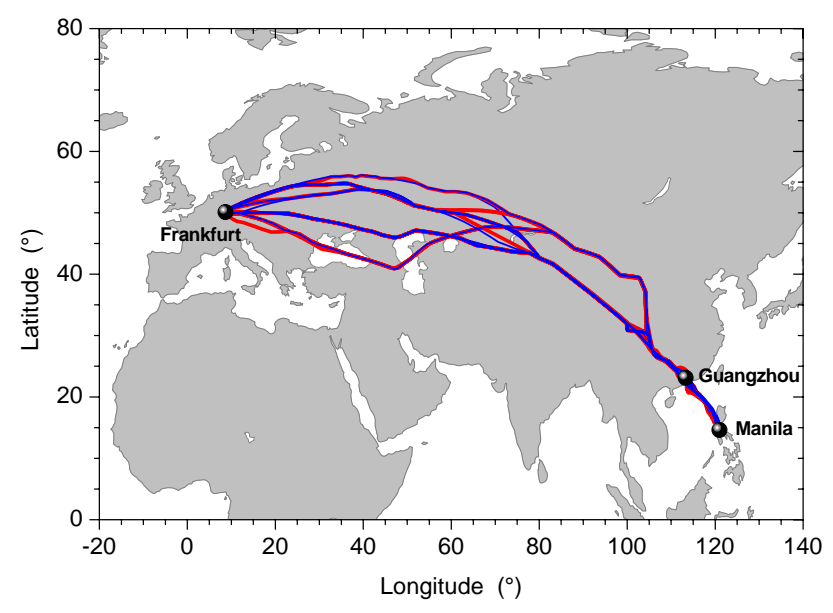

Fig. 1. Geographic sampling area and individual CARIBIC flight tracks on the South-East Asia route, which were used for the cluster analysis in this study. Red color indicates summer flights (15), blue winter flights (17). Each outward and return flight consists of two flight legs with a brief stopover in Guangzhou (China).

et al., 1999b), the discrimination of air masses near the extra tropical tropopause (Borchi and Marenco, 2002; Borchi et al., 2005), or aircraft-derived profiles of trace gas and particulate pollution in the lower troposphere (Taubman et al., 2006; Hains et al., 2008).

The choice of a statistical analysis method for a given problem is not straight forward, as different methods partially overlap in the resulting information content (Backhaus et al., 2006). Therefore we experimented with different combinations of statistical analysis methods. In the following sections, the univariate and multivariate statistical analysis methods are briefly described. Details, in particular on mathematical background, are given for instance in Backhaus et al. (2006). All statistical analyses were performed with the commercial software code SPSS ${ }^{\circledR}$ (statistical computer software SPSS, version 11.0.1, SPSS Inc., Chicago, Illinois, USA; http://www.spss.com).

\subsection{Univariate statistical methods}

Explorative data analysis methods are generally used to get an overview of the data set and to detect suspicious data points (outliers) and errors. However, there are no fixed prescriptions as to how an explorative data analysis should be conducted. The choice of methods clearly depends on the respective data sets and on the subsequent multivariate statistical methods (Brosius, 2006; Backhaus et al., 2006; Leyer and Wesche, 2007).

If an outlier in one variable gets identified, it is most often useful to exclude the respective data point from analysis, because outliers can affect results strongly and complicate conclusions (Brosius, 2006; Backhaus et al., 2006). The present CARIBIC data were examined by using the SPSS ${ }^{\circledR}$ 
functions extreme values, percentiles, M-estimators, and (the multivariate) hierarchical cluster analyses (here the single linkage algorithm, cf. Sect. 3.2). The SPSS $^{\circledR}$ sub function extreme values identifies the five highest and lowest values of a variable together with the corresponding row numbers of the data matrix. By using this function, erroneous data points could be eliminated. In statistical analyses percentiles are often used to visualize the distribution of values. Thereby, extremes that show values for instance above the $95 \%$ percentile can be eliminated from data sets. Here, we refrained from this relatively crude elimination by percentiles, because extreme values of tracers are likely to help to reveal the origin of an air mass. Nevertheless, we did use percentiles in this study to verify the elimination of outliers process resulting by the above listed techniques. M-estimators are statistical indices derived by combining all values of one investigated variable to a mean value. To identify the influence of extreme values so-called maximum likelihood estimators can be used. Herein individual values get different weights according to their distance to the remaining values of the respective variable. For that purpose SPSS ${ }^{\circledR}$ offers four different indices. If the distribution of values is not symmetric, the four M-estimators differ significantly from the arithmetic mean. In this work, M-estimators were recalculated after an elimination step to examine the effect. Finally, the multivariate single linkage algorithm was used, which is highly suited to find outliers in data sets by separating clusters of highly different numbers of data points (Brosius, 2006; Backhaus et al., 2006) (cf. Sect. 3.2). For both seasonal data sets, the fraction of outliers was below $0.4 \%$.

Before starting the multivariate analysis, two data processing steps were carried out. Although not necessarily required, normalization of the data might help data analysis (Leyer and Wesche, 2007). For that reason the original variables of the CARIBIC data subsets were examined for normal distribution by using histograms and significance tests (e.g. the Kolmogorov-Smirnov test). If the applied tests revealed a non-normal distribution, the corresponding original variable was transformed by applying either the logarithm, the square, or the radical function in order to bring it in a nearly normally distributed shape (Leyer and Wesche, 2007). After having evaluated each variable for normal distribution, the original variables were processed by centering and standardization. This step is recommended since measured variables often have highly different value ranges (Brosius, 2006; Backhaus et al., 2006; Leyer and Wesche, 2007). Centering and standardization leads to comparability of respective variables. For centering purposes the difference between the measured value and the arithmetic mean was calculated. Afterwards, within the standardization, this difference was divided by the standard deviation of the variable distribution. Accordingly, these processed variables (hereafter called zparameters) have a mean of zero and a standard deviation of one.

\subsection{Multivariate statistical methods}

Atmospheric science often deals with complex relationships involving more than one variable. One of the main problems is to identify the controlling parameters among a large number of variables that subsequently can be used as input for multivariate analysis (Brosius, 2006; Backhaus et al., 2006; Leyer and Wesche, 2007). Therefore we occasionally used the principal component analysis (PCA) before applying the cluster analysis (CA).

PCA is one possible method to reduce the complexity of a data set by attributing as much as possible of the total variance of the original data to fewer newly defined variables (Brosius, 2006; Backhaus et al., 2006). This data reduction is accomplished by finding linear combinations of original variables, also referred to as factors or principal components (PCs). The resulting linear combinations are chosen to be uncorrelated with each other and account for successively smaller fractions of the total variance.

The data reduction in the course of the PCA can also be used to successive eliminate "ineffective" variables of a data set, e.g. by applying the MSA (Measure of Sampling Adequacy) criterion (Brosius, 2006; Backhaus et al., 2006). The MSA criterion enables to investigate whether or not a variable contributes significantly to the variance of the data set. It compares the single and partial correlations between variables. High MSA values (close to one) generally indicate that a particular variable is "useful" and should be kept in the data set. In two of the analysis procedures we applied the MSA criterion to eliminate variables and directly afterwards PCA was aborted (cf. Fig. 2). Consequently, for these two procedures no PCs were extracted but instead the z-parameters, identified as relevant, were used for the subsequent analysis methods.

The CA is a technique to group similar observations or data points into classes called clusters (Brosius, 2006; Backhaus et al., 2006). In our case, these clusters helped to discriminate air masses and hence to identify particle origins. Two kinds of CAs, referred to as the hierarchical cluster analysis (HCA) and $\mathrm{K}$-means cluster analysis (KCA) were applied. As HCA algorithms, two common types, the single linkage and Ward algorithms, were used. The single linkage algorithm is particularly capable of separating clusters with highly different numbers of data points. Often it separates a few large and many small clusters, with the small clusters allowing the identification of outliers in data sets (Brosius, 2006; Backhaus et al., 2006). This valuable characteristic was used in addition to the univariate methods listed in Sect. 3.1. The Ward algorithm uses the heterogeneity of the cluster as criterion for clustering data points, whereby the variance within clusters should become minimal. Since homogeneity inside clusters is the goal of the Ward algorithm, it is the preferred algorithm in many applications of CAs (Leyer and Wesche, 2007). The Ward algorithm can be regarded as practical classification algorithm for 


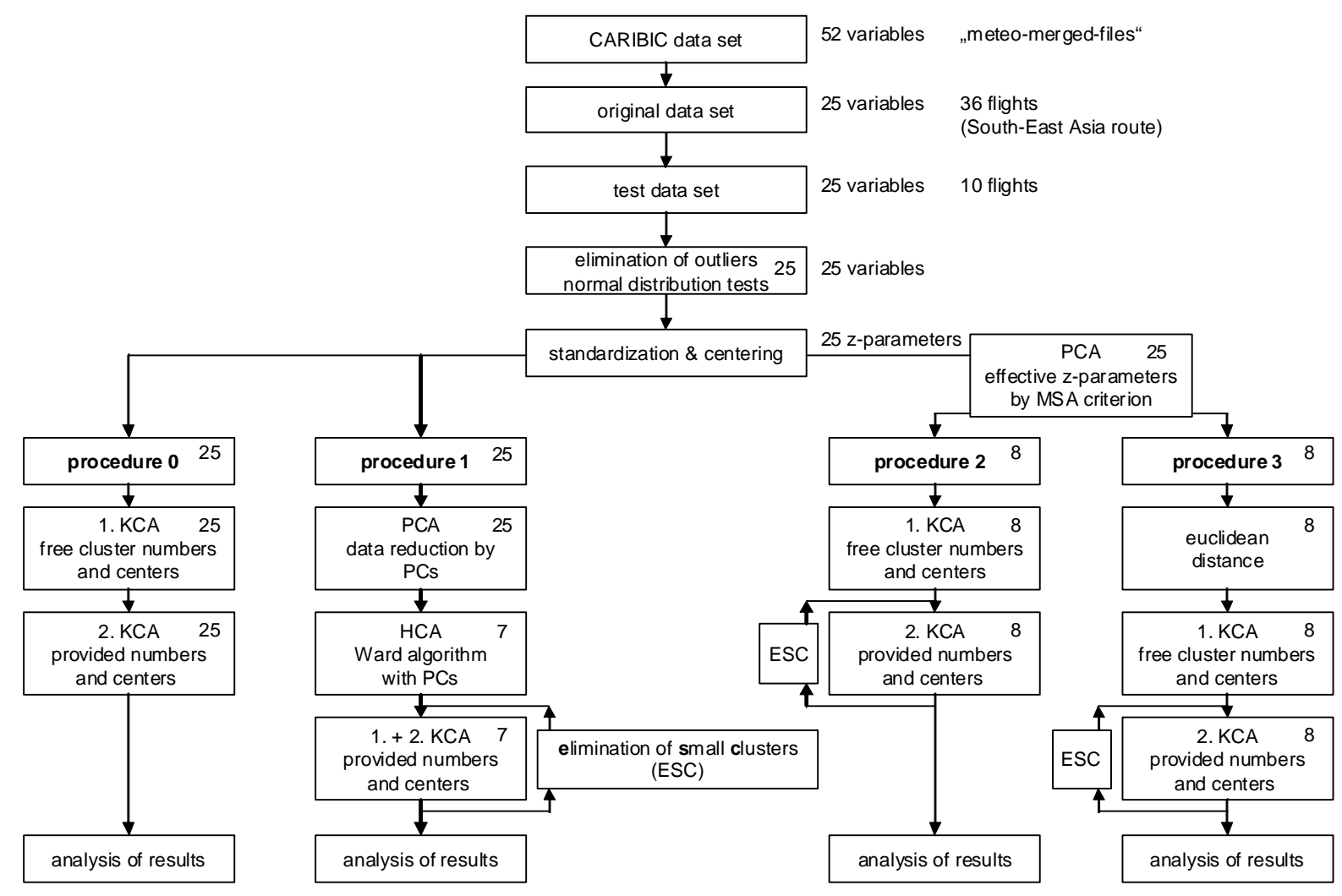

Fig. 2. Flow diagram for composition and implementation of the statistical analysis methods of the original - and test data sets. Numbers in the upper right corner of the boxes give the number of investigated z-parameters or principal components (in procedure 1), respectively.

the objective of this study, because it mostly finds uniform and compact clusters in data sets and even promotes their formation (Backhaus et al., 2006; Leyer and Wesche, 2007). Unfortunately, HCA requires a large computer capacity and has the drawback that once a data point is attributed to a particular cluster, a reassignment to a more appropriate cluster in a later step of the HCA is not feasible. Consequently, nonhierarchical techniques like KCA are commonly preferred. For the KCA a number of clusters and cluster centers have to be provided by the user and then the KCA assigns each data point to that cluster that has the nearest centroid (arithmetic mean). The clustering itself is performed in a way that the sum of distances within a cluster is minimized. Assignment or permutation of data points is not concluded before the "optimal" clustering is found.

As briefly explained, the different CA techniques have their advantages and disadvantages and can provide dissimilar results. While the entire purpose is to minimize the differences between the data points within clusters (homogeneity) and maximize the differences between clusters (heterogeneity), the essential challenge is to find the "correct" clustering. This question clearly depends on the nature of the data set and the problem in question. Therefore we tested and compared different techniques of both HCA and KCA.

\section{3 "Optimal" multivariate statistical method for CARIBIC data}

With increasing complexity of statistical analysis computing time is rising. Thus a first issue is whether simple and quick statistical methods can provide similar results as complex and more elaborate methods do. To this end we tested four different procedures (cf. Fig. 2).

Procedure 0 is the simplest but crudest of all, clustering z-parameters (cf. Sect. 3.1) of particular CARIBIC data subsets with a KCA only. From the outset it was not known how many clusters would be required for an optimal clustering of CARIBIC data targeting the meaningful separation of air masses. Consequently, all clustering methods described here were tested for the range of four to seven clusters. Procedure 0 is the quickest, because it does not need further data preprocessing before the CA. To check the quality of the resulting clustering, various scatter plots, each involving two tracers, were investigated. As an example, Fig. 3 shows the scatter plot of $\mathrm{O}_{3}$ vs. $\mathrm{CO}$ for the six-cluster separation process, in order to check the homogeneity of resulting stratosphere clusters. A comparison based on a cluster separation with five clusters yielded similar results. In all four graphs (a-d) the well-known negative correlation between $\mathrm{O}_{3}$ and $\mathrm{CO}$ appears which marks 


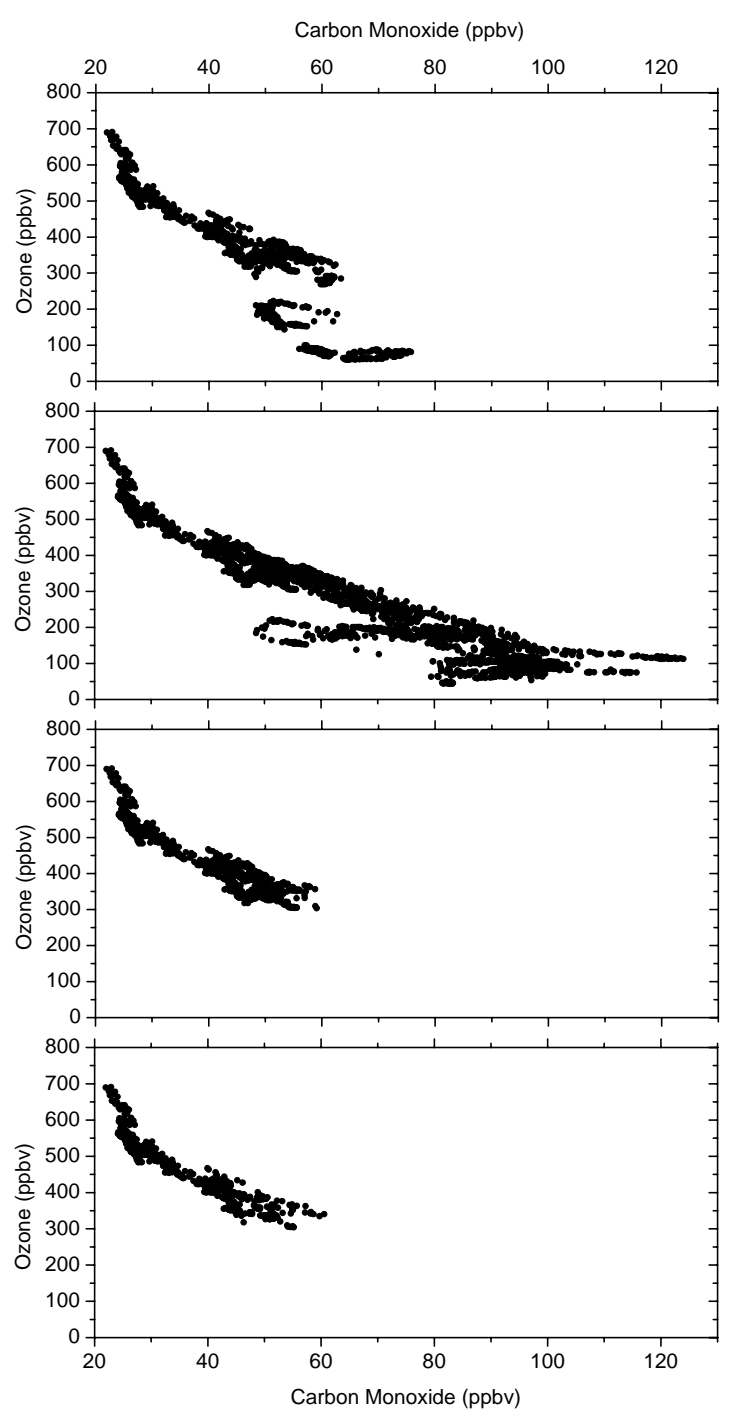

(a)

(b)

(c)

Fig. 3. $\mathrm{O}_{3}-\mathrm{CO}$-scatter plots for the stratosphere clusters of the test data set (six-cluster separation). (a) procedure 0 , (b) procedure 1 , (c) procedure 2, and (d) procedure 3_50.

the extra-tropical tropopause transition layer sandwiched between the tropopause and the unperturbed lowermost stratosphere (Hoor et al., 2002). Figure 3 shows that the stratosphere cluster of procedure 0 (Fig. 3a) contains data points with $\mathrm{O}_{3}$ values from nearly $50 \mathrm{ppbv}$ up to $700 \mathrm{ppbv}$ whilst $\mathrm{CO}$ values are always below $80 \mathrm{ppbv}$. Since $\mathrm{O}_{3}$ values below 100 ppbv describe almost always tropospheric air (Zahn and Brenninkmeijer, 2003) and procedure 0 grouped data points with upper tropospheric up to stratospheric values into the same cluster, this clustering is certainly not satisfactory.

In procedure 1 the numbers of z-parameters were first reduced by applying a PCA before the CA. With the extracted PCs an HCA and afterwards a KCA was carried out. This procedure follows the methodology developed in Borchi and Marenco (2002) and Borchi et al. (2005), who applied it to a similar data set, however with a smaller number of parameters. In the course of KCA another modification in comparison to procedure 0 was made. Very small clusters, representing only very small fractions of all data points $(<1 \%)$, characterize individual events, like crossing an individual cumulonimbus. They are not representative for the intended large-scale air mass-based characterization of submicrometer aerosol particles in the UT/LMS. Thus they were eliminated and the KCA was reapplied.

Correlation analyses in the course of the PCA exposed the very low load of some essential z-parameters - like the particle number concentrations - on the extracted PCs. This results in a too large information loss concerning the variance of the particle number concentrations, which is not desired for the overall purpose of this study. Concerning its separation capability, procedure 1 shows similar results as procedure 0 (cf. Fig. $3 \mathrm{~b}$ ). $\mathrm{O}_{3}$ values lie again between 50 and $700 \mathrm{ppbv}$, but this time $\mathrm{CO}$ values of even more than $120 \mathrm{ppbv}$ are reached, clearly indicating tropospheric air. For this reason, also procedure 1 was excluded from the main statistical analyses of the CARIBIC data subsets.

As procedures 0 and 1 turned out to be inadequate for the purpose of this study new procedures were developed. Procedure 2 also starts with a PCA of z-parameters. After a correlation analysis concerning adequacy for subsequent multivariate statistical analysis, the most effective and relevant z-parameters, not PCs, were identified by using the MSA criterion in the already described manner. The method's suggestion to eliminate all particle number concentrations was however disregarded, because this would of course not allow the identification of aerosol origins. Only the particle number concentration for particles larger than $18 \mathrm{~nm}$ diameter $\left(\mathrm{N}_{18}\right)$ was excluded because it is highly correlated with $\mathrm{N}_{12}$. The following eight remaining z-parameters finally entered a KCA: $\mathrm{O}_{3}$ (ozone), $\mathrm{CO}$ (carbon monoxide), $\mathrm{NO}_{\mathrm{y}}$ (reactive odd nitrogen), $\mathrm{H}_{2} \mathrm{O}_{\text {gas }}$ (water vapor), $\mathrm{CH}_{3} \mathrm{CN}$ (acetonitrile), $\mathrm{CH}_{3} \mathrm{COCH}_{3}$ (acetone), $\mathrm{N}_{4-12}$ (nucleation mode particles), and $\mathrm{N}_{12}$ (Aitken mode particles). Like before (procedure 1) too small clusters were eliminated and the KCA reapplied. Procedure 2 yields better results compared to procedures 0 and 1. For instance, data points of stratospheric and tropospheric air masses were separated in clearly different clusters as can be seen in Fig. 3c.

Like procedure 2, procedure 3 starts with a PCA, but afterwards an additional step was performed. The idea was that generally those air masses that have been recently influenced by a particle or trace gas source or sink show a clear signature in the respective tracer. The more the air mass ages or mixes with other air masses, the more its tracer signature wanes, while being transformed into background air. In terms of an $\mathrm{n}$-dimensional data set in the z-space, aged or well-mixed air masses should be located close to the origin of the coordinate system. Air masses recently influenced by a source or sink process should show a greater distance to the origin. The idea behind procedure 3 was to eliminate this atmospheric 
background enabling a clearer clustering of the remaining data points. Therefore the Euclidean distance from the origin of the coordinate system was calculated for each data point. Hereafter $25 \%$ and $50 \%$ of data points, respectively, with the smallest distance to the origin were eliminated. The remaining data points were then clustered according to procedure 2 . However, procedure 3 did not significantly improve the separation of resulting clusters in comparison to procedure 2 (cf. Fig. 3d). Moreover, procedure 3 always showed the same results for the two seasonal data subsets as procedure 2 . The likely reason for this similarity is that procedure 2 generates a background air cluster close to the origin by its own, which has the same effect as eliminating the data points close to the origin. Consequently, only results of procedure 2 will be discussed below.

\section{Results and discussion}

The results of the cluster analysis for the summer and winter data sets are presented in Sect. 4.1 and 4.2, respectively. At the outset, it is conspicuous that there is a significant difference in the total number of data points between summer (15 609) and winter (25 111), compared to the only slightly different number of flights (15 and 17, respectively). This difference is due to missing values of individual parameters in the meteo-merged files (cf. Sect. 2) and can be explained by an increasing instrument reliability with time.

In a first step, cluster separations with four through seven clusters were tested and compared for each season separately to find the optimal cluster separation, as was done with the test data set (Sect. 3.3). On the basis of whether the particular clusters were clearly separated and assignable to a source signature, and how data points were reassigned between the different cluster separations, the optimal cluster separation was chosen. The investigation of the test data set had already pointed out that the optimal number of clusters for the present data set lies at five or six clusters. Separations with four clusters or less are not satisfactory as not all identifiable types of air masses get their own cluster. On the other hand having a too large number of clusters leads to a splitting of existing clusters into two parts, e.g. the stratosphere cluster splits into two stratosphere clusters. Again results of procedure 3 were used to confirm the optimal number of clusters obtained for procedure 2 . Eventually the optimal cluster separation for both seasonal data sets was achieved with five clusters. The identified air masse types or clusters are:

\section{Lowermost stratospheric air}

(found in summer and winter, "stratosphere cluster" (LMS), in the following graphs indicated by yellow symbols)
2. Mixed air of the tropopause region (summer and winter, "tropopause cluster" (TP), orange symbols)

3. Air masses influenced by high clouds, probably mostly deep convective

(summer only, "high clouds cluster" (HC), blue symbols)

4. Air of the free tropospheric background

(summer and winter, "free troposphere cluster" (FT), green symbols)

5. Air masses which had contact with the boundary layer (summer and winter, "boundary layer cluster" (BL), red symbols).

Further clusters, such as for aircraft emissions, possibly based on elevated $\mathrm{NO}_{\mathrm{y}}$ and particle number concentration values (Hermann et al., 2008), were not found with the described statistical analysis methods in the present data set. The most likely reason for not finding such a cluster is that the aircraft density on our specific SouthEast Asia route, although growing rapidly in recent years, is still lower by at least a factor of two, compared to the highly dense North-Atlantic flight route (cf. e.g. the Global Aviation Emissions Inventory of the FAA, SAGE, Fig. 11, http://www.faa.gov/about/office_org/headquarters offices/aep/models/sage/). But even there only 5-20\% of the high particle number concentration peaks could be attributed to aircraft emission plumes (Hermann et al., 2008). Secondly, a minor reason, clear aircraft emission peaks in the aerosol number concentration are usually short, on the order of a few seconds only. Hence, due to the $10 \mathrm{~s}$ averaging in the meteo-merged files, clear and large aircraft signals might be diminished. These reasons do not exclude that on other flight routes an aircraft emission cluster might be found with the methodology described here.

\subsection{Results for boreal summer}

Figure 4 shows the distribution of the five clusters obtained with procedure 2 applied to the summer data set. Data points are displayed with respect to the three original variables $\mathrm{O}_{3}$, $\mathrm{CO}$, and $\mathrm{N}_{12}$ and in the respective cluster color. Additionally, Table 3 lists the results of procedure 2 in terms of arithmetic means, medians, and relative standard deviations for the original variables. In Table 3 (and also in Table 4) the order of clusters is arranged according to the number of data points. In summer, there is one bigger cluster, the tropopause cluster, and four approximately evenly divided medium-sized clusters.

The summer stratosphere cluster is characterized by lowest $\mathrm{CO}$ (32-57 ppbv) and highest $\mathrm{O}_{3}$ values (287-483 ppbv). Here and in the following mixing ratios and concentration ranges are indicated by the $25 \%$ - and $75 \%$-percentiles. 
Table 3. Arithmetic means, medians, and standard derivations for the five-cluster separation of procedure 2 of the summer data set. The circular parameters wind direction an local time are not displayed because the respective averages are meaningless. Abbreviations for the clusters are: lowermost stratosphere $=\mathrm{LMS}$, tropopause $=\mathrm{TP}$, high clouds $=\mathrm{HC}$, free troposphere $=\mathrm{FT}$, and boundary layer $=\mathrm{BL}$. The total number of data points was 15609 .

\begin{tabular}{|c|c|c|c|c|c|c|c|c|c|c|c|c|c|c|c|}
\hline \multirow{2}{*}{$\begin{array}{l}\text { Summer } \\
\text { Cluster name }\end{array}$} & \multicolumn{5}{|c|}{ Mean } & \multicolumn{5}{|c|}{ Median } & \multicolumn{5}{|c|}{ Standard Deviation(\%) } \\
\hline & $\mathrm{TP}$ & $\mathrm{HC}$ & LMS & BL & FT & $\mathrm{TP}$ & $\mathrm{HC}$ & LMS & BL & FT & $\mathrm{TP}$ & $\mathrm{HC}$ & LMS & BL & FT \\
\hline Parameter/\% of Data & 30.7 & 19.9 & 17.9 & 16.7 & 14.8 & & & & & & & & & & \\
\hline Altitude (feet) & 36316 & 32298 & 37124 & 36179 & 33906 & 36457 & 31528 & 37452 & 37038 & 33538 & 5.1 & 12 & 3.8 & 6.5 & 7.8 \\
\hline Julian Day (0-365) & 185 & 191 & 176 & 175 & 187 & 174 & 188 & 173 & 173 & 147 & 18 & 16 & 16 & 17 & 16 \\
\hline Latitude $\left({ }^{\circ}\right)$ & 41 & 34 & 49 & 35 & 46 & 43 & 33 & 50 & 33 & 47 & 19 & 30 & 10 & 32 & 11 \\
\hline Longitude $\left({ }^{\circ}\right)$ & 76 & 92 & 52 & 84 & 56 & 84 & 104 & 45 & 104 & 54 & 36 & 32 & 47 & 40 & 49 \\
\hline Wind Speed (kn) & 52 & 29 & 47 & 32 & 28 & 50 & 27 & 47 & 26 & 24 & 54 & 51 & 46 & 73 & 60 \\
\hline Static Temperature $(\mathrm{K})$ & 227 & 236 & 225 & 226 & 227 & 228 & 240 & 225 & 227 & 227 & 2.9 & 4.4 & 1.9 & 3.2 & 3.4 \\
\hline Vertical Velocity (feet/min) & 11.1 & 11.4 & 2.1 & 9.7 & 10.9 & 2.3 & -1.0 & 0.4 & 2.2 & -0.4 & 1158 & 954 & 5310 & 1246 & 1022 \\
\hline Static Pressure (mbar) & 225 & 274 & 216 & 227 & 253 & 222 & 281 & 212 & 216 & 256 & 9.5 & 17 & 7.0 & 12 & 13 \\
\hline Potential Temperature (K) & 348 & 343 & 349 & 346 & 336 & 352 & 347 & 349 & 351 & 335 & 2.8 & 3.0 & 2.5 & 3.1 & 1.9 \\
\hline $\mathrm{H}_{2} \mathrm{O}_{\text {gas }} \mathrm{mr}(\mathrm{ppmv})$ & 34 & 688 & 21 & 215 & 142 & 28 & 446 & 17 & 117 & 88 & 73 & 102 & 72 & 175 & 127 \\
\hline $\mathrm{H}_{2} \mathrm{O}_{\text {cloud }} \mathrm{mr}(\mathrm{ppmv})$ & 0 & 20 & 0 & 12 & 21 & 0 & 0 & 0 & 0 & 0 & 1478 & 337 & 2911 & 644 & 715 \\
\hline $\mathrm{O}_{3} \mathrm{mr}(\mathrm{ppbv})$ & 134 & 65 & 378 & 90 & 130 & 120 & 67 & 361 & 78 & 114 & 43 & 28 & 29 & 41 & 32 \\
\hline $\mathrm{NO}_{\mathrm{y}} \mathrm{mr}$ (ppbv) & 0.96 & 0.48 & 1.98 & 1.60 & 0.94 & 0.44 & 2.04 & 0.84 & 1.52 & 41 & 41 & 53 & 23 & 57 & 35 \\
\hline $\mathrm{CO} \mathrm{mr}(\mathrm{ppbv})$ & 72 & 92 & 45 & 100 & 96 & 70 & 89 & 48 & 95 & 95 & 16 & 16 & 30 & 23 & 15 \\
\hline $\mathrm{N}_{4-12}\left(\right.$ particles $\left./ \mathrm{cm}^{3} \mathrm{STP}\right)$ & 783 & 1464 & 1300 & 6710 & 363 & 506 & 465 & 861 & 2825 & 157 & 145 & 231 & 161 & 152 & 163 \\
\hline $\mathrm{N}_{12}$ (particles $\left./ \mathrm{cm}^{3} \mathrm{STP}\right)$ & 2499 & 2028 & 2300 & 11664 & 8274 & 2125 & 1687 & 1864 & 7215 & 4777 & 54 & 72 & 157 & 114 & 139 \\
\hline $\mathrm{N}_{18}\left(\right.$ particles $\left./ \mathrm{cm}^{3} \mathrm{STP}\right)$ & 2136 & 1628 & 1940 & 9036 & 6958 & 1813 & 1378 & 1642 & 5729 & 4014 & 53 & 73 & 135 & 114 & 139 \\
\hline Potential Vorticity (PVU) & 2.6 & 0.4 & 6.9 & 1.7 & 2.5 & 2.5 & 0.3 & 7.0 & 0.4 & 1.3 & 63 & 81 & 24 & 121 & 79 \\
\hline Eq. Pot. Temperature (K) & 347 & 343 & 347 & 346 & 336 & 351 & 348 & 348 & 351 & 334 & 2.7 & 3.1 & 2.4 & 3.0 & 1.9 \\
\hline Vertical Wind Speed $(\mathrm{Pa} / \mathrm{s})$ & -0.4 & -0.42 & 0.09 & -0.25 & 0.21 & 0.01 & -0.11 & 0.14 & -0.05 & 0.19 & 1419 & 378 & 548 & 397 & 336 \\
\hline Cloud Cover $(0-1)$ & 0.02 & 0.24 & 0.01 & 0.17 & 0.05 & 0.00 & 0.12 & 0.00 & 0.03 & 0.00 & 312 & 114 & 516 & 146 & 280 \\
\hline $\mathrm{CH}_{3} \mathrm{CN} \mathrm{mr}$ (pptv) & 127 & 112 & 114 & 144 & 122 & 125 & 112 & 115 & 142 & 121 & 18 & 19 & 18 & 21 & 18 \\
\hline $\mathrm{CH}_{3} \mathrm{COCH}_{3} \mathrm{mr}$ (pptv) & 509 & 776 & 269 & 940 & 1233 & 493 & 732 & 253 & 917 & 1173 & 41 & 33 & 65 & 30 & 31 \\
\hline
\end{tabular}

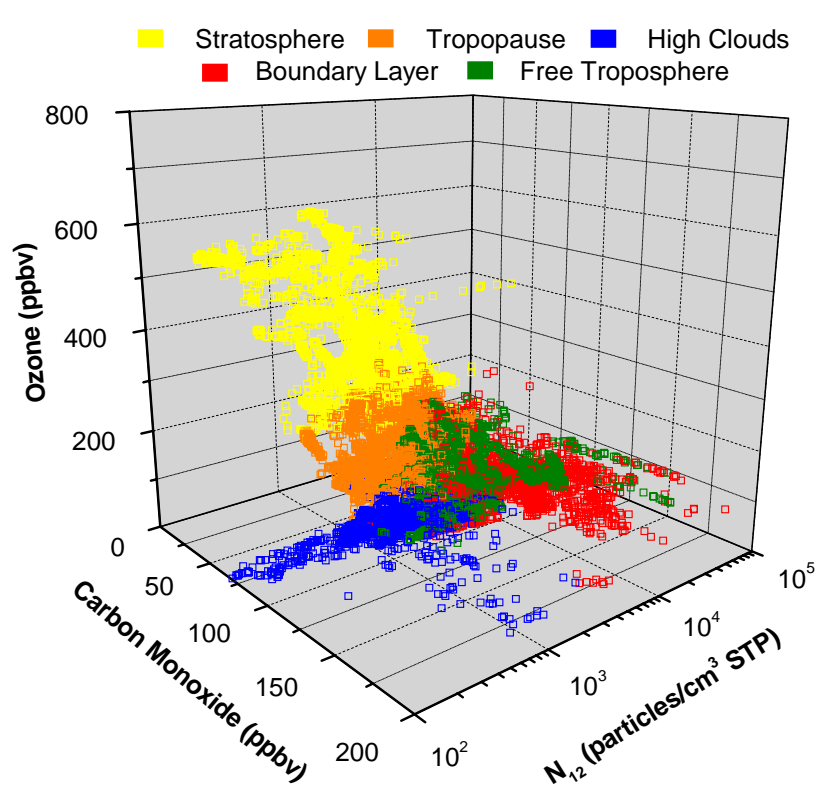

Fig. 4. $\mathrm{O}_{3}-\mathrm{CO}-\mathrm{N}_{12}$ scatter plot for the five-cluster separation of the summer data set (procedure 2).
Aitken mode particle number concentrations $\left(\mathrm{N}_{12}\right)$ are low to intermediate (1110-2820 particles $/ \mathrm{cm}^{3}$ STP). Additional indicators for stratospheric air masses are the highest averages for $\mathrm{NO}_{\mathrm{y}}$ and PV (cf. Table 3). Furthermore, this cluster combines the data points with the lowest averages for the trace gases $\mathrm{H}_{2} \mathrm{O}, \mathrm{CO}$, and $\mathrm{CH}_{3} \mathrm{COCH}_{3}$, which have their sources almost exclusively near the ground. The stratosphere cluster is the only summer cluster, which is strongly dominated by individual flight sequences, here namely the CARIBIC flights 150-153 and 194-197, which contribute each about one third of all data points of this cluster. Consequently the cluster values should be regarded typical for early summer conditions. All other individual contributions of flight sequences to a summer cluster where below $30 \%$.

Because of the typical aircraft cruise altitudes, the tropopause cluster is the largest summer cluster and contains almost $31 \%$ of all data points (Table 3). Its $\mathrm{O}_{3}$ values lie mainly in the range of $87-177 \mathrm{ppbv}, \mathrm{CO}$ values in the range of 63-79 ppbv. The tropopause cluster has the second highest averages for $\mathrm{O}_{3}$ and $\mathrm{PV}$, and the second lowest averages for $\mathrm{H}_{2} \mathrm{O}, \mathrm{CO}$, and $\mathrm{CH}_{3} \mathrm{COCH}_{3}$ (Table 3). $\mathrm{N}_{12}$ values lie in the intermediate range of $1650-3140$ particles $/ \mathrm{cm}^{3}$ STP. An analysis of static pressure, altitude (cf. Table 3 ), and vertical cross sections for the potential vorticity (http://www.knmi. 
Table 4. Arithmetic means, medians, and standard derivations for the five-cluster separation of procedure 2 of the winter data set. The circular parameters wind direction an local time are not displayed because the respective averages are meaningless. Abbreviations for the clusters are: lowermost stratosphere $=\mathrm{LMS}$, tropopause $=\mathrm{TP}$, free troposphere $=$ FT, and boundary layer $=$ BL. The total number of data points was 25111 .

\begin{tabular}{|c|c|c|c|c|c|c|c|c|c|c|c|c|c|c|c|}
\hline \multirow{2}{*}{$\begin{array}{l}\text { Winter } \\
\text { Cluster Name }\end{array}$} & \multicolumn{5}{|c|}{ Mean } & \multicolumn{5}{|c|}{ Median } & \multicolumn{5}{|c|}{ Standard Deviation (\%) } \\
\hline & FT-1 & $\mathrm{TP}$ & LMS & FT-2 & BL & FT-1 & $\mathrm{TP}$ & LMS & FT-2 & BL & FT-1 & $\mathrm{TP}$ & LMS & FT-2 & BL \\
\hline Parameter/\% of Data & 32.4 & 29.1 & 16.1 & 14.8 & 7.6 & & & & & & & & & & \\
\hline Altitude (feet) & 34923 & 35460 & 36088 & 33514 & 36091 & 35043 & 36440 & 37440 & 33146 & 37033 & 7.4 & 6.1 & 6.3 & 7.6 & 4.5 \\
\hline Julian Day (0-365) & 357 & 5 & 39 & 41 & 317 & 349 & 349 & 38 & 67 & 293 & 54 & 55 & 48 & 58 & 48 \\
\hline Latitude $\left({ }^{\circ}\right)$ & 40 & 44 & 48 & 37 & 36 & 43 & 46 & 49 & 37 & 34 & 29 & 17 & 13 & 25 & 36 \\
\hline Longitude $\left({ }^{\circ}\right)$ & 73 & 69 & 52 & 81 & 83 & 79 & 69 & 47 & 92 & 97 & 44 & 36 & 48 & 37 & 43 \\
\hline Wind Speed $(\mathrm{Kn})$ & 54 & 52 & 48 & 61 & 49 & 49 & 47 & 47 & 53 & 47 & 55 & 55 & 43 & 59 & 50 \\
\hline Static Temperature $(\mathrm{K})$ & 219 & 217 & 222 & 223 & 220 & 218 & 216 & 222 & 222 & 220 & 3.6 & 2.8 & 2.5 & 4.0 & 2.5 \\
\hline Vertical Velocity (feet/min) & 3.1 & 12.5 & 18.4 & 8.5 & 6.5 & -0.2 & 0.5 & 1.5 & -1.9 & 2.7 & 4377 & 851 & 741 & 1184 & 1179 \\
\hline Static Pressure (mbar) & 241 & 234 & 227 & 257 & 227 & 238 & 223 & 212 & 260 & 216 & 13 & 11 & 11 & 12 & 8.1 \\
\hline Potential Temperature (K) & 329 & 329 & 339 & 330 & 336 & 325 & 328 & 341 & 324 & 339 & 3.7 & 2.8 & 3.2 & 3.5 & 3.1 \\
\hline $\mathrm{H}_{2} \mathrm{O}_{\text {gas }} \mathrm{mr}(\mathrm{ppmv})$ & 46 & 21 & 8 & 69 & 75 & 34 & 20 & 7 & 63 & 58 & 87 & 40 & 39 & 60 & 80 \\
\hline $\mathrm{H}_{2} \mathrm{O}_{\text {cloud }} \mathrm{mr}$ (ppmv) & 2 & 0 & 0 & 2 & 3 & 0 & 0 & 0 & 0 & 0 & 384 & 1644 & 3481 & 432 & 400 \\
\hline $\mathrm{O}_{3} \mathrm{mr}(\mathrm{ppbv})$ & 57 & 135 & 356 & 67 & 59 & 54 & 128 & 335 & 60 & 55 & 34 & 32 & 38 & 38 & 31 \\
\hline $\mathrm{NO}_{\mathrm{y}} \mathrm{mr}$ (ppbv) & 0.33 & 0.72 & 1.23 & 0.36 & 1.11 & 0.31 & 0.73 & 1.11 & 0.31 & 0.93 & 60 & 34 & 38 & 55 & 71 \\
\hline $\mathrm{CO} \mathrm{mr}(\mathrm{ppbv})$ & 87 & 68 & 40 & 92 & 106 & 85 & 67 & 38 & 91 & 92 & 16 & 17 & 22 & 15 & 27 \\
\hline $\mathrm{N}_{4-12}\left(\right.$ particles $\left./ \mathrm{cm}^{3} \mathrm{STP}\right)$ & 2571 & 665 & 883 & 239 & 25152 & 1159 & 443 & 303 & 158 & 15618 & 127 & 126 & 494 & 140 & 113 \\
\hline $\mathrm{N}_{12}\left(\right.$ particles $\left./ \mathrm{cm}^{3} \mathrm{STP}\right)$ & 3671 & 1825 & 1338 & 2395 & 20006 & 3083 & 1680 & 1014 & 1642 & 12019 & 66 & 49 & 138 & 98 & 111 \\
\hline $\mathrm{N}_{18}$ (particles/cm $\left.{ }^{3} \mathrm{STP}\right)$ & 3018 & 1589 & 1116 & 2101 & 16065 & 2627 & 1465 & 863 & 1454 & 9905 & 62 & 48 & 122 & 99 & 109 \\
\hline Potential Vorticity (PVU) & 1.3 & 3.8 & 6.5 & 0.8 & 0.6 & 1.3 & 3.9 & 6.6 & 0.5 & 0.3 & 78 & 36 & 16 & 98 & 143 \\
\hline Eq. Pot. Temperature (K) & 329 & 328 & 338 & 329 & 336 & 325 & 327 & 339 & 324 & 339 & 3.6 & 2.8 & 3.2 & 3.4 & 3.1 \\
\hline Vertical Wind Speed $(\mathrm{Pa} / \mathrm{s})$ & 0.08 & 0.04 & -0.01 & 0.08 & 0.10 & 0.14 & 0.03 & 0.03 & 0.13 & 0.17 & 823 & 1476 & 4014 & 1068 & 486 \\
\hline Cloud Cover (0-1) & 0.07 & 0.01 & 0.00 & 0.10 & 0.07 & 0.00 & 0.00 & 0.00 & 0.00 & 0.01 & 225 & 509 & 995 & 200 & 186 \\
\hline $\mathrm{CH}_{3} \mathrm{CN} \mathrm{mr}$ (pptv) & 89 & 107 & 112 & 121 & 126 & 88 & 104 & 110 & 117 & 119 & 23 & 21 & 19 & 25 & 39 \\
\hline $\mathrm{CH}_{3} \mathrm{COCH}_{3} \mathrm{mr}$ (pptv) & 446 & 330 & 147 & 558 & 698 & 440 & 320 & 140 & 518 & 653 & 32 & 35 & 50 & 33 & 35 \\
\hline
\end{tabular}

nl/samenw/campaign_support/CARIBIC) gives further confidence that data points of this cluster were measured almost exclusively in the tropopause region.

The high clouds cluster contains the data points with the lowest $\mathrm{O}_{3}$ values (55-75 ppbv) and medium-range $\mathrm{CO}$ values (84-97 ppbv). It is characterized by the highest $\mathrm{H}_{2} \mathrm{O}_{\text {gas }}$ and ECMWF-derived vertical wind speed values (Table 3, note: negative values of the vertical wind speed indicate updraft). Furthermore, the $\mathrm{NO}_{\mathrm{y}}$ values are the lowest, probably due to wet scavenging in deep convective clouds (e.g. Garrett et al., 2006). Interestingly, this high clouds cluster seems to have two orthogonal branches, one dominant, with low $\mathrm{CO}$, $\mathrm{CH}_{3} \mathrm{COCH}_{3}$ (not shown), and $\mathrm{N}_{12}$ values, the other one with high $\mathrm{CO}, \mathrm{CH}_{3} \mathrm{COCH}_{3}$ (not shown), and $\mathrm{N}_{12}$ values. These two branches probably represent the transport of relatively clean air and of polluted air, respectively.

The boundary layer cluster is characterized by the highest $\mathrm{CO}$ (87-106 ppbv) and $\mathrm{N}_{12}$ values (429013400 particles $/ \mathrm{cm}^{3} \mathrm{STP}$ ). More importantly, it has also the highest averages for $\mathrm{N}_{4-12}$ and $\mathrm{CH}_{3} \mathrm{CN}$ (Table 3), the latter being one of the best indicators for biomass burning (de Gouw et al., 2003, 2006). Admittedly, there are data points in the boundary layer cluster, which could also be attributed to the high clouds cluster, or vice versa, as for instance deep convective clouds transport boundary layer air into the UT. Nevertheless, there are clear differences in trace gas and particle concentrations, which led to the separation of the two clusters.

The free troposphere cluster comprises, as expected, the data points around the center of the point cloud in Fig. 4. It is characterized mostly by intermediate parameter values, but stands out with the second highest $\mathrm{N}_{12}$ and the highest $\mathrm{CH}_{3} \mathrm{COCH}_{3}$ values (Table 3).

Figure 4 displays the general problem of cluster analysis: data points are only assignable to dissimilar clusters, if they differ significantly at least in one variable. If the air masses are old and well mixed characteristic fingerprints get lost. Considering this principal problem, Fig. 4 shows a surprisingly successful separation of air masses. As additional check for the above cluster attribution, we display the geographic distribution of the clusters along the South-East Asia route in Fig. 5. Data points of the stratosphere are located north of $40^{\circ}$ latitude, with a concentration in the region between Germany and the Ural mountains. This concentration is also indicated by the median values of $50^{\circ}$ latitude and $45^{\circ}$ longitude in Table 3 . The tropopause cluster comprises data points from the whole sampling area, which is again indicated by the median values 


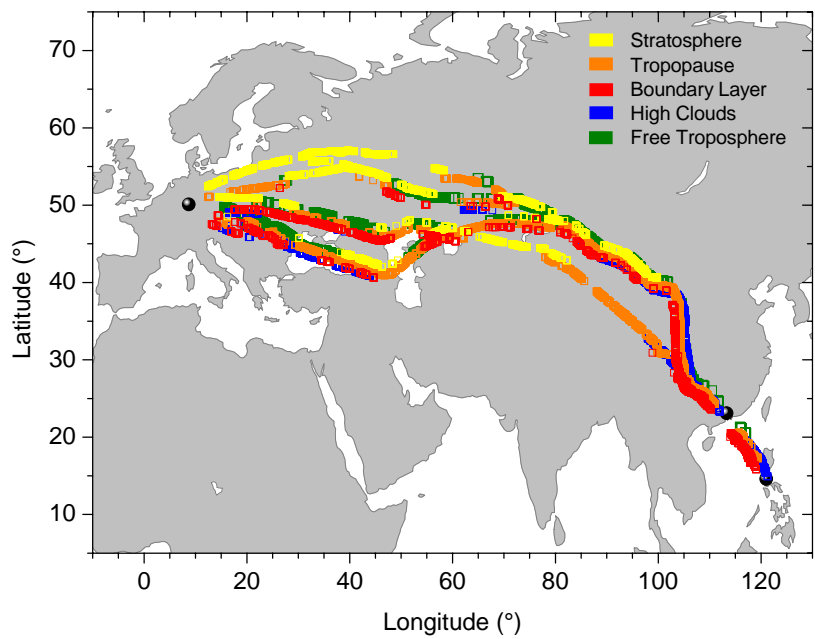

Fig. 5. Regional distribution of data points for the five-cluster separation of the summer data set (procedure 2). Colors give the attribution of the data points to its cluster. For the sake of clarity, all data points of a cluster were shifted by up to $\pm 1^{\circ}$ in longitude and/or latitude with respect to the flight tracks.

of $43^{\circ}$ latitude and $84^{\circ}$ longitude. Indeed, vertical cross sections for the potential vorticity (http://www.knmi.nl/samenw/ campaign_support/CARIBIC) show the flight track to be close to the tropopause for each summer flight, with the exception of one to two hours in the vicinity of Guangzhou. For the short flight legs between Guangzhou and Manila (high tropopause levels) the attribution of tropopause air is not as clear as for the longer flight legs. However, these tropopause data points show on average the greatest distance to the cluster centroid, and hence could be possibly attributed to another cluster when using a different clustering method. Furthermore they account only for less than $3 \%$ of the tropopause cluster.

The data points of the high clouds cluster are mainly found over China and South-East Asia (cf. latitude and longitude medians in Table 3), but also over Eastern Europe. This is in agreement with satellite data from the International Satellite Cloud Climatology Project (ISCCP), which show high frequencies particularly for deep convective clouds in summer for both regions (cf. http://isccp.giss.nasa.gov/products/ browsed2.html). Likewise, the boundary layer cluster is found mainly over China plus South-East Asia and Eastern Europe. A remarkable difference is a concentration of boundary layer cluster points ( $\sim 22 \%$ of the points) over the Ukraine and southern Russia. Considering the elevated level of $\mathrm{CH}_{3} \mathrm{CN}$ for this cluster, these signals might arise from cropland burning, which is an agricultural practice in these regions. According to Korontzi et al. (2006) there is a maximum in agriculture fire activity in the Ukraine in July/August, by field burning after the harvesting of winter and spring wheat. Indeed, MODIS satellite pictures of fire activity (http://rapidfire.sci.gsfc.nasa.gov/firemaps/) in-

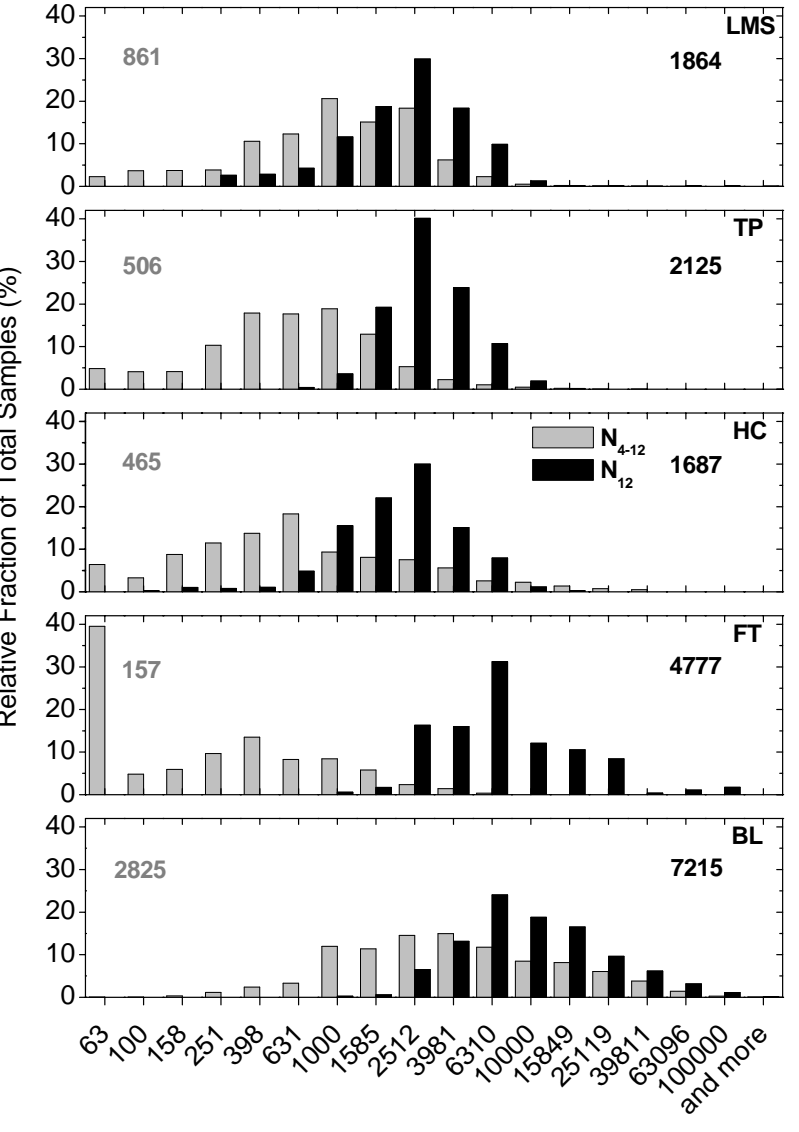

Particle Number Concentration (particles/cm ${ }^{3}$ STP)

Fig. 6. $\mathrm{N}_{4-12}$ and $\mathrm{N}_{12}$ histograms for the five-cluster separation for the summer data set (procedure 2). Columns are representative for the concentration window between the particle number concentrations given below the columns and the value at the next lower tick. Numbers indicate the respective medians. Abbreviations used for the clusters are: lowermost stratosphere $=\mathrm{LMS}$, tropopause $=\mathrm{TP}$, high clouds $=\mathrm{HC}$, free troposphere $=\mathrm{FT}$, and boundary layer $=\mathrm{BL}$.

dicate such a fire maximum for July/August in the region of the boundary layer cluster points also for the years 2006 and 2007. The data points of the free troposphere cluster in summer are mainly located over Eastern Europe and Central Asia.

Finally, Fig. 6 compares the histograms of nucleation $\left(\mathrm{N}_{4-12}\right)$ and Aitken mode $\left(\mathrm{N}_{12}\right)$ particle number concentrations for the five summer clusters. These histograms and the respective particles number concentrations can be regarded as typical for the specific air masse type in the northern hemispheric mid-latitudes and subtropics over the Eurasian continent in summer. As Fig. 6 shows, $\mathrm{N}_{12}$ increases when going from the stratosphere (1110 2820 particles $/ \mathrm{cm}^{3} \mathrm{STP}$ ) downward into the free troposphere (3260-8270 particles $/ \mathrm{cm}^{3}$ STP). The highest concentrations in this study are found for the boundary layer cluster (4290 13390 particles $/ \mathrm{cm}^{3}$ STP). Similar Aitken mode UT/LMS 
concentrations were not only found by previous CARIBIC studies for other flight routes (Hermann et al., 2003, 2008), but also by other research groups. For the LMS, Aitken mode particle number concentrations are reported in the range of 100-2500 particles/cm ${ }^{3}$ STP (de Reus et al., 1998, 1999). For UT, over Western Europe, Schröder et al. (2002) measured somewhat lower concentrations in the range of 300-2500 particles/cm ${ }^{3}$ STP. Singh et al. (2002) present concentrations in the range of 1000-8000 particles $/ \mathrm{cm}^{3} \mathrm{STP}$ over the North Atlantic in fall. Similar numbers (30010000 particles $/ \mathrm{cm}^{3} \mathrm{STP}$ ) were observed by Minikin et al. (2003) over Western Europe.

The nucleation mode particles, $\mathrm{N}_{4-12}$, can be regarded as an indicator for recent new particle formation events (cf. e.g. Hermann et al., 2003), as these particles have UT lifetimes of hours only (Williams et al., 2002). In summer, the stratosphere and the tropopause clusters show a similar range of $\mathrm{N}_{4-12}$ values of 260-1700 particles $/ \mathrm{cm}^{3} \mathrm{STP}$, whereby the tropopause cluster distribution is shifted a little bit to lower concentrations (cf. averages in Table 3). Hence particle formation takes place in these regions. The high clouds cluster yields the broadest $\mathrm{N}_{4-12}$ distribution, indicative for clouds acting both as particle sink and as particle source (cf. Weigelt et al., 2009). The highest $\mathrm{N}_{4-12}$ values are found in the boundary layer cluster (12607530 particles $/ \mathrm{cm}^{3} \mathrm{STP}$ ), a clear indication for particle formation in such air masses. As transport into the UT is mostly associated with clouds, and nucleation mode particles do not survive this transport in clouds, because either transport time is too long (e.g. in warm conveyor belts) or they are effectively scavenged by cloud droplets (e.g. in deep convective clouds; Ekman et al., 2006), it is very likely that the boundary layer provides only the precursor gases but particle formation takes place in the UT. On the other hand, the free troposphere cluster shows the lowest $\mathrm{N}_{4-12}$ values $\left(0-450\right.$ particles $\left./ \mathrm{cm}^{3} \mathrm{STP}\right)$. This is in agreement with vertical profiles of nucleation mode particles, which often show a C-shaped profile with high concentrations in the boundary layer and at the tropopause, but lower values inbetween (Schröder et al., 2002; Singh et al., 2002; Krejci et al., 2003). Nucleation mode particle number concentrations for the mid-latitude UT reported by Schröder et al. (2002) (50-8000 particles $/ \mathrm{cm}^{3}$ STP) and Singh et al. (2002) (100010000 particles $/ \mathrm{cm}^{3} \mathrm{STP}$ ) fall into the same range as observed in this study.

\subsection{Results for boreal winter}

Figure 7 illustrates the results of the five cluster separation obtained with procedure 2 for the winter data set. The respective cluster means, medians, and relative standard deviations for the original variables are listed in Table 4. In winter, there are two bigger clusters, two medium-sized clusters, and one small cluster.

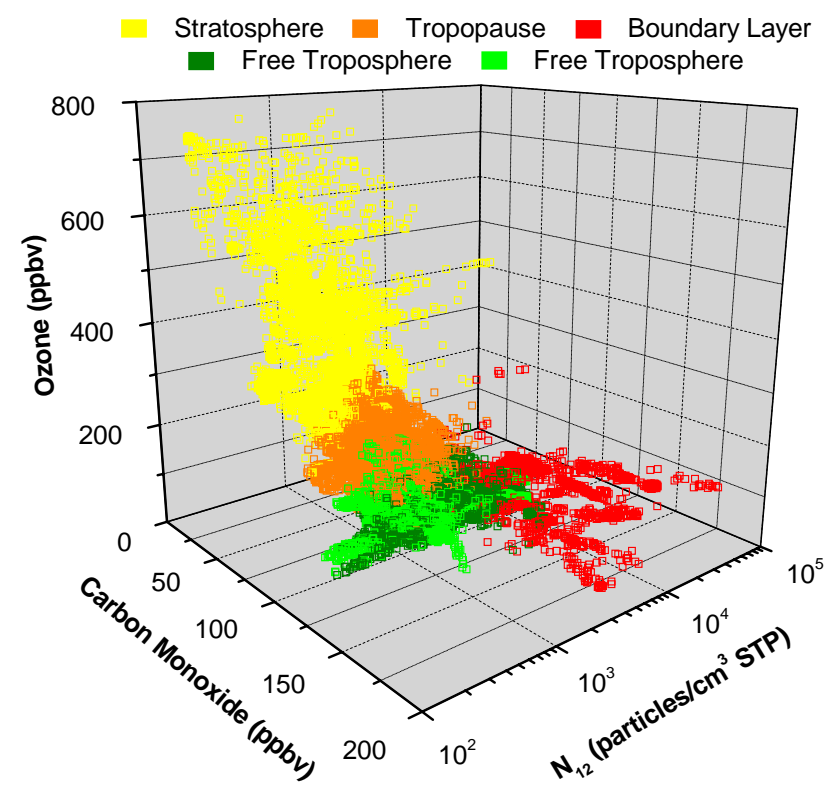

Fig. 7. $\mathrm{O}_{3}-\mathrm{CO}-\mathrm{N}_{12}$ scatter plot for the five-cluster separation of the winter data set (procedure 2).

The winter stratosphere cluster is of medium size with a smaller fraction of data points compared to summer. This is not expected, because having the same flight levels and flight routes as well as a lower local winter tropopause more data points should lie in the stratosphere. Apparently, in winter some of the data points with stratospheric influence were attributed to the tropopause cluster, as indicated by the higher PV averages in winter compared to summer. The stratosphere cluster combines again the highest $\mathrm{O}_{3}$ values (249-434 ppbv) with the greatest absolute $\mathrm{O}_{3}$ variance and the lowest $\mathrm{CO}$ values (34-46 ppbv). $\mathrm{N}_{12}$ values are low with 720-1450 particles/cm ${ }^{3}$ STP. Again, the stratospheric cluster is characterized by the highest averages of $\mathrm{NO}_{\mathrm{y}}$ and $\mathrm{PV}$ and the lowest averages of $\mathrm{H}_{2} \mathrm{O}, \mathrm{CO}$, and $\mathrm{CH}_{3} \mathrm{COCH}_{3}(\mathrm{Ta}-$ ble 4). As in the summer data, the tropopause cluster is large, has the second highest averages for $\mathrm{O}_{3}$ and $\mathrm{PV}$, and the second lowest averages for $\mathrm{H}_{2} \mathrm{O}, \mathrm{CO}$, and $\mathrm{CH}_{3} \mathrm{COCH}_{3}$ (Table 4). $\mathrm{N}_{12}$ values lie in the intermediate range of 1250 2130 particles $/ \mathrm{cm}^{3}$ STP.

The winter boundary layer cluster is again not only characterized by the overall highest $\mathrm{CO}$ (84-126 ppbv) and $\mathrm{N}_{12}$ (7220-22 760 particles $/ \mathrm{cm}^{3}$ STP) values, but also by the highest seasonal averages in $\mathrm{CH}_{3} \mathrm{COCH}_{3}, \mathrm{CH}_{3} \mathrm{CN}$, and $\mathrm{N}_{4-12}$. This cluster is the smallest winter cluster. No high clouds cluster was found for the winter data set, which can not be attributed to the frequency of cloud encounters, which is approximately equal for the summer and winter data set. The difference between the two seasons is rather caused by different cloud types and cloud properties. In summer, a larger fraction of the clouds over the continent are deep convective clouds, which change the UT air more strongly 


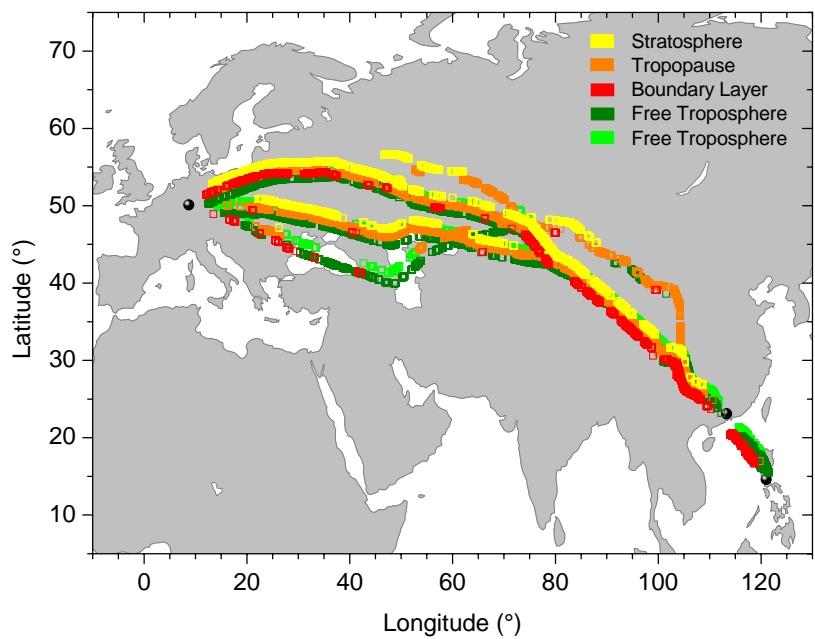

Fig. 8. Regional distribution of data points for the five-cluster separation of the winter data set (procedure 2). Same representation as in Fig. 5.

than other cloud types do. In winter, the convective activity over the Eurasian continent is smaller (cf. ISCCP; http://isccp.giss.nasa.gov/products/browsed2.html).

The remaining data points of the winter data set are distributed between a large (FT-1, dark green) and a mediumsized (FT-2, light green) free troposphere cluster. In the $\mathrm{O}_{3}$ CO-N $\mathrm{N}_{12}$ scatter plot, they are hardly to distinguish, which is also confirmed by similar parameter averages in Table 4. Interestingly, the majority of FT-2 data points were obtained in February/March (73\%), while for FT-1 most of the data points belong to the period October-December $(65 \%)$. The FT-2 cluster is dominated by one flight sequence, 224-227, which contributes about $45 \%$ of all data points to this cluster, while for the FT-1 cluster (as well as for the stratosphere and the tropopause cluster) the individual contribution of flight sequences is again below $30 \%$.

The geographic distribution of the winter clusters on the South-East Asia route is presented in Fig. 8. Data points of the stratosphere cluster again form a data point cloud for the section between Germany and the Ural Mountains (cf. latitude and longitude medians in Table 4). But in contrast to summer, there are also stratospheric data points below $40^{\circ} \mathrm{N}$, between Kazakhstan and China. This change is caused by the seasonal variation of the tropopause height. The tropopause cluster spreads again over the whole flight route, but this time there is only one data point on the short flight leg between Guangzhou and Manila. Data points of the boundary layer cluster are mainly found over China and South-East Asia (cf. latitude and longitude medians in Table 4), but there is a second concentration of data points over Eastern Europe above $52^{\circ}$ latitude. This cluster and particular the data point cloud above $52^{\circ}$ are strongly dominated by data from the CARIBIC flight 166 (Frankfurt-
Guangzhou, 19 October 2006), which contributes about 55\% of the cluster data points. This flight is characterized by strong pollution plumes and was already discussed by Slemr et al. (2009). The respective air masses over Eastern Europe probably have their origin over the Iberian Peninsula, where a low pressure system over the western Atlantic Ocean together with convective activity over the Iberian Peninsula let to a transport of boundary-layer-influenced air into the upper troposphere (http://www.knmi.nl/samenw/campaign support/CARIBIC; http://www.wetterzentrale.de). The light and the dark green free troposphere clusters describe almost $60 \%$ of all data points of the winter data set. They are scattered over the whole sampling area, whereby the medium sized-cluster (FT-2, light green) is concentrated more over Central Asia, China, and South-East Asia. This is indicated also by the lower latitude and higher longitude medians in Table 4 compared to the dark green cluster (FT-1). Furthermore, FT-2 shows the higher $\mathrm{H}_{2} \mathrm{O}, \mathrm{CH}_{3} \mathrm{COCH}_{3}$, and $\mathrm{CH}_{3} \mathrm{CN}$ mixing ratios of both clusters, but the lower $\mathrm{N}_{4-12}$ and $\mathrm{N}_{12}$ values, while the other trace gases are nearly similar. Evidently, the cluster separation for winter is less satisfactory than for summer, because a clear attribution to a "source" is not easily done. There are two possible reasons for this difference. First, stronger vertical transport over the continent in summer due to high-reaching deep convective clouds could lead to younger air masses and hence clearer air mass characteristics. Secondly, the lower chemical reactivity of most trace gases in winter leads to a more homogeneous distribution and hence less clear air mass characteristics.

Finally, in Fig. 9 the histograms of $\mathrm{N}_{4-12}$ and $\mathrm{N}_{12}$ for the five winter clusters are displayed. Similar to summer, the $\mathrm{N}_{12}$ values increase from the stratosphere into the troposphere, however concentrations are generally lower. In the stratosphere only 720-1450 particles $/ \mathrm{cm}^{3}$ STP are found, in the free troposphere $1100-4560$ particles $/ \mathrm{cm}^{3}$ STP. The boundary layer cluster has the highest $\mathrm{N}_{12}$ values with 7220 22760 particles $/ \mathrm{cm}^{3} \mathrm{STP}$. This cluster comprises also the highest $\mathrm{N}_{4-12}$ values with 6240-29500 particles/cm ${ }^{3}$ STP. In the stratosphere, at the tropopause, and also partly in the free troposphere particle formation appears to be less frequent, given that $\mathrm{N}_{4-12}$ values are mostly below 850 particles $/ \mathrm{cm}^{3}$ STP (75\%-percentile). Only in the larger free troposphere cluster (FT-1, dark green) nucleation events are more frequent, indicated by concentrations typically in the range of 530-3930 particles/ $\mathrm{cm}^{3}$ STP. Again, particle number concentrations are in agreement with previous CARIBIC studies and literature values (e.g. Young et al., 2007). 


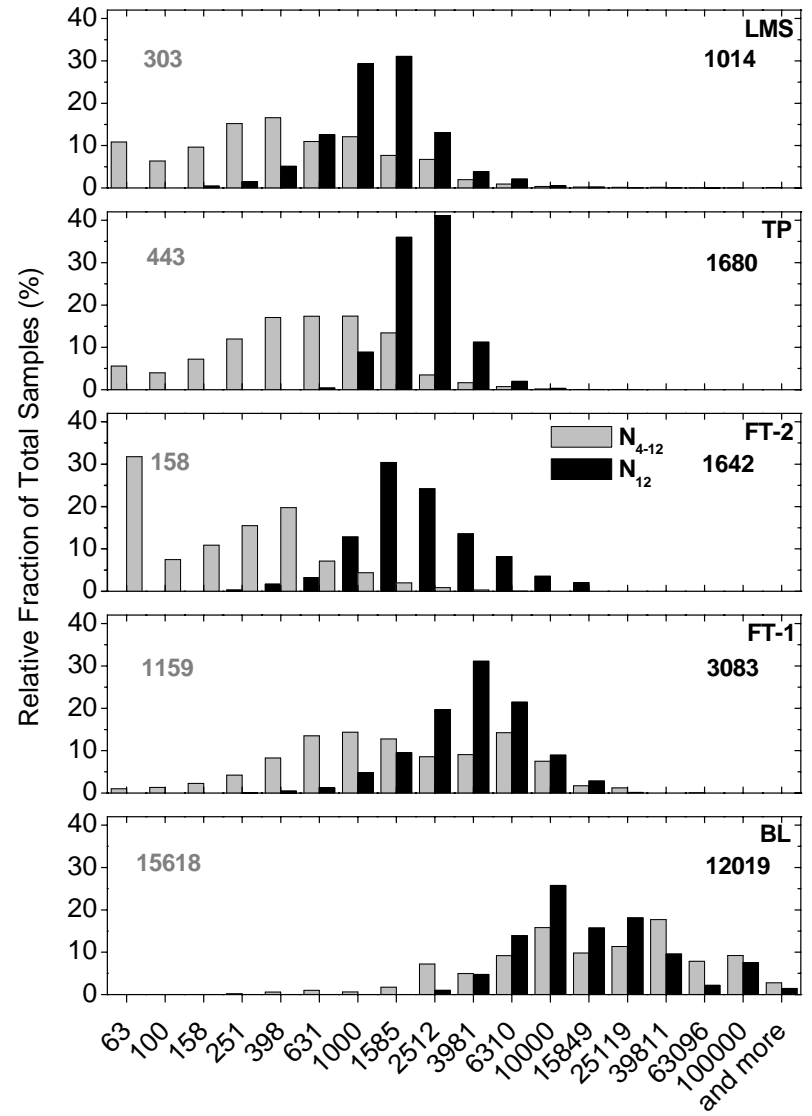

Particle Number Concentration (particles/cm³ STP)

Fig. 9. $\mathrm{N}_{4-12}$ and $\mathrm{N}_{12}$ histograms for the five cluster separation of the winter data set (procedure 2). Same representation as in Fig. 6.

\section{Summary}

The origin of nucleation mode and Aitken mode particles in the upper troposphere and lowermost stratosphere (UT/LMS) at northern mid-latitudes and subtropics was investigated using cluster analysis methods. The analyses are based on in situ measurements of trace gases and aerosol particles conducted during flights between Germany and South-East Asia with the CARIBIC (Civil Aircraft for Regular Investigation of the Atmosphere Based on an Instrument Container) measurement system. Four cluster analysis methods were applied to the data set and were tested for their capability to separate the data points into meaningful clusters. With the preferred method applied to seasonal data subsets for summer and winter five cluster or air mass types were identified: stratosphere, tropopause, high clouds, free troposphere, and boundary layer influenced. Other source clusters, like aircraft emissions, were not identified in the present data set with the used methods. While the cluster separation for summer works satisfactory well, the results for winter are less clear and interpretation is more difficult. This difference is

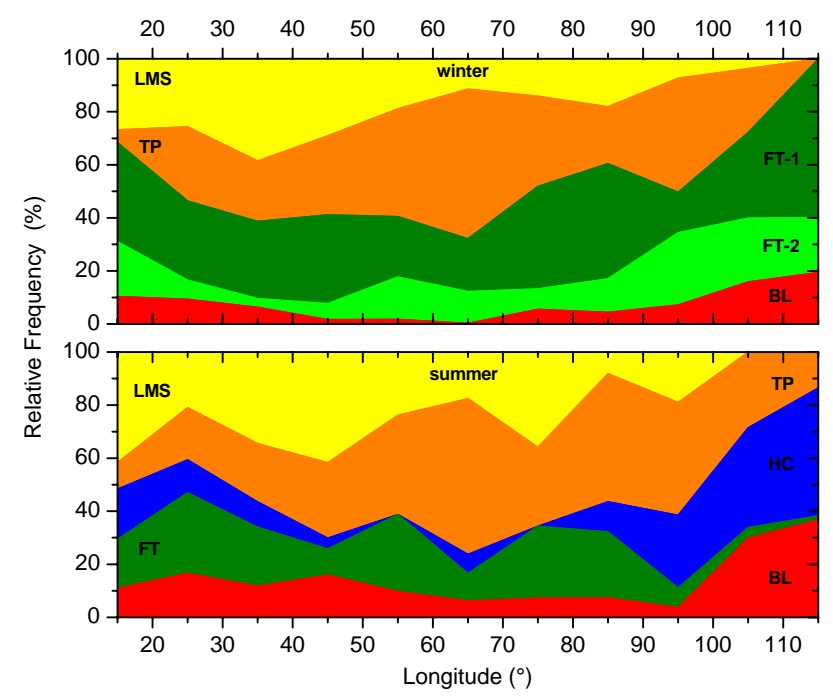

Fig. 10. Relative frequency of cluster types along the SouthEast Asia route. Data points were partitioned into $10^{\circ}$ longitude bins. Cluster abbreviations are: lowermost stratosphere $=$ LMS, tropopause $=\mathrm{TP}$, high clouds $=\mathrm{HC}$, free troposphere $=\mathrm{FT}$, and boundary layer $=\mathrm{BL}$.

either caused by the different vertical transport pathways or the different chemical lifetimes of trace gases in the two seasons. Figure 10 summarizes the results of the cluster analysis by showing the relative frequency of cluster or air mass types in $8-12 \mathrm{~km}$ altitude along the South-East Asia route (Fig. 1). The data represent the two years period early summer 2006 to late winter 2008, and might look slightly differently for other years. As the diagram represents also a north south distribution, because of the flight route, data points from the stratosphere and the tropopause region are concentrated more to the left and high clouds data points more to the right.

This study presents the first seasonal submicrometer particle number concentration data sets in the UT/LMS over the Eurasian continent (Eastern Europe, Central Asia, East Asia, and South-East Asia) and analyses the origin of these particles. Aitken mode particle number concentrations show a clear vertical gradient with the lowest values in the lowermost stratosphere (750-2820 particles $/ \mathrm{cm}^{3}$ STP, minimum of the two $25 \%$ - and maximum of the two $75 \%$-percentiles of both seasons) and the highest values for the boundarylayer-influenced air (4290-22 760 particles $/ \mathrm{cm}^{3}$ STP). Nucleation mode particles are also highest in the boundarylayer-influenced air (1260-29500 particles $/ \mathrm{cm}^{3} \mathrm{STP}$, but are lowest in the free troposphere (0-450 particles $\left./ \mathrm{cm}^{3} \mathrm{STP}\right)$, in agreement with previous studies. The obtained particle number concentrations for air mass types can be useful as input parameters for and for validating the results of global atmospheric aerosol models.

This study is the first step in the effort to identify the origin of aerosol particles in the UT/LMS by using multivariate 
statistical analysis methods. In the future, the results could be improved by enlarging the analyzed data set using data from other CARIBIC routes. By including trajectory information as well as hydrocarbon and halocarbon trace gas mixing ratios obtained from the CARIBIC whole air sampler, additional information on the particle origin might be derived. However, as the merging of a low-resolution, high-information-content datasets with the high-resolution datasets used here, increases the amount of data handling and computational burden enormously, this additional step was beyond the scope of this work.

\section{Appendix A}

\section{List of abbreviations}

$\mathrm{CA}=$ cluster analysis

CARIBIC $=$ Civil Aircraft for Regular Investigation of the Atmosphere based on an Instrument Container

ECMWF $=$ European Centre for Medium-Range Weather Forecasts

$\mathrm{HCA}=$ hierarchical cluster analysis

$\mathrm{KCA}=\mathrm{K}$-means cluster analysis

LMS = lowermost stratosphere

$\mathrm{mr}=$ mixing ratio

MSA = measure of sampling adequacy

$\mathrm{PC}=$ principle component

$\mathrm{PCA}=$ principle component analysis

ppbv $=$ parts per billion by volume $\left(10^{-9}\right)$

ppmv $=$ parts per million by volume $\left(10^{-6}\right)$

pptv $=$ parts per trillion by volume $\left(10^{-12}\right)$

$\mathrm{PV}=$ potential vorticity

PVU = potential vorticity unit $\left(10^{-6} \mathrm{~K} \mathrm{~m}^{2} \mathrm{~kg}^{-1} \mathrm{~s}^{-1}\right)$

SPSS $=$ Statistical Package for the Social Sciences

STP $=$ standard temperature and pressure $(273.15 \mathrm{~K}$, $1013.25 \mathrm{hPa}$ )

$\mathrm{UT}=$ upper troposphere

Acknowledgements. We are deeply grateful to Andreas Waibel and Thomas Dauer (Lufthansa Passage and Lufthansa Technik) for their support of CARIBIC and to Dieter Scharffe and Claus Koeppel (Max Planck Institute for Chemistry) for the equipment support and container operation. The development of the CARIBIC system was financially supported by the German Ministry of Education and Science (AFO 2000 program) and its operation benefits from the European Commission's DGXII Environment RTD 4th, 5th, 6th, and 7th Framework programs.

Edited by: M. Petters

\section{References}

Backhaus, K., Erichson, B., Plinke, W. and Weiber, R.: Multivariate Analysemethoden, 11th edition, Springer, Berlin, 830 pp., 2006.

Bell, N., Koch, D., and Shindell, D. T.: Impacts of chemicalaerosol coupling on tropospheric ozone and sulfate simulations in a general circulation model, J. Geophys. Res., 110, D14305, doi:10.1029/2004JD005538, 2005.

Borchi, F. and Marenco, A.: Discrimination of air masses near the extratropical tropopause by multivariate analyses from MOZAIC data, Atmos. Environ., 36, 1123-1135, 2002.

Borchi, F., Oikonomou, E., and Marenco, A.: Extratropical case study of stratosphere-troposphere exchange using multivariate analyses from MOZAIC aircraft data, Atmos. Environ., 39, 6537-6549, 2005.

Brenninkmeijer, C. A. M., Crutzen, P. J. , Fischer, H., Güsten, H., Hans, W., Heinrich, G., Heintzenberg, J., Hermann, M., Immelmann, T., Kersting, D., Maiss, M., Nolle, M., Pitscheider, A., Pohlkamp, H., Scharffe, D., Specht, K., and Wiedensohler, A.: CARIBIC civil aircraft for global measurement of trace gases and aerosols in the tropopause region, J. Atmos. Ocean. Tech., 16, 1373-1383, 1999.

Brenninkmeijer, C. A. M., Crutzen, P., Boumard, F., Dauer, T., Dix, B., Ebinghaus, R., Filippi, D., Fischer, H., Franke, H., Frieß, U., Heintzenberg, J., Helleis, F., Hermann, M., Kock, H. H., Koeppel, C., Lelieveld, J., Leuenberger, M., Martinsson, B. G., Miemczyk, S., Moret, H. P., Nguyen, H. N., Nyfeler, P., Oram, D., O'Sullivan, D., Penkett, S., Platt, U., Pupek, M., Ramonet, M., Randa, B., Reichelt, M., Rhee, T. S., Rohwer, J., Rosenfeld, K., Scharffe, D., Schlager, H., Schumann, U., Slemr, F., Sprung, D., Stock, P., Thaler, R., Valentino, F., van Velthoven, P., Waibel, A., Wandel, A., Waschitschek, K., Wiedensohler, A., Xueref-Remy, I., Zahn, A., Zech, U., and Ziereis, H.: Civil Aircraft for the regular investigation of the atmosphere based on an instrumented container: The new CARIBIC system, Atmos. Chem. Phys., 7, 4953-4976, 2007,

http://www.atmos-chem-phys.net/7/4953/2007/.

Brenninkmeijer, C. A. M.: http://www.caribic-atmospheric.com, last access: April 2009.

Brosius, F.: SPSS 14, Das mitp-Standardwerk, 1st edition, MitpVerlag, Bonn, 1056 pp., 2006.

de Gouw, J. A., Warneke, C., Parrish, D. D., Holloway, J. S., Trainer, M., and Fehsenfeld, F. C.: Emission sources and ocean uptake of acetonitrile $\left(\mathrm{CH}_{3} \mathrm{CN}\right)$ in the atmosphere, J. Geophys. Res., 108, 4329, doi:10.1029/2002JD002897, 2003.

de Gouw, J. A., Warneke, C., Stohl, A., Wollny, A. G., Brock, C. A., Cooper, O. R., Holloway, J. S., Trainer, M., Fehsenfeld, F. C., Atlas, E. L., Donnelly, S. G., Stroud, V., and Lueb, A.: Volatile organic compounds composition of merged and aged forest fire plumes from Alaska and western Canada, J. Geophys. Res., 110, D10303, doi:10.1029/2005JD006175, 2006.

de Reus, M., Ström, J., Kulmala, M., Pirjola, L., Lelieveld, J., Schiller, C., and Zöger, M.: Airborne aerosol measurements in the tropopause region and the dependence of new particle formation on preexisting particle number concentration, J. Geophys. Res., 103, 31255-31263, 1998.

de Reus, M., Ström, J., Hoor, P., Lelieveld, J., and Schiller, C.: Particle production in the lowermost stratosphere by convective lifting of the tropopause, J. Geophys. Res., 104, 23935-23940, 1999. 
Dorling, S. R. and Davis, T. D.: Extending cluster analysis synoptic meteorology links to characterise chemical climates at six northwest European monitoring stations, Atmos. Environ., 29(2), 145-167, 1995.

Ekman, A. M. L., Wang, C., Ström, J., and Krejci, R.: Explicit simulation of aerosol physics in a cloud-resolving model: Aerosol transport and processing in the free troposphere, J. Atmos. Sci., 63, 682-696, 2006.

Fine, S. S.: http://www.arl.noaa.gov, last access: February 2008.

Garrett, T. J., Avey, J., Palmer, P. I., Stohl, A., Neuman, J. A., Brock, C. A., Ryerson, T. B., and Holloway, J. S.: Quantifying wet scavenging processes in aircraft observations of nitric acid and cloud condensation nuclei, J. Geophys. Res., 111, D23S51, doi:10.1029/2006JD007416, 2006.

Gerstengarbe, F.-W., Werner, P. C., and Rüge, U.: Katalog der Großwetterlagen Europas (1981-1998), nach Paul Hess und Helmuth Brezowski, 5th edition, Berichte des Deutschen Wetterdienstes 113, Potsdam/Offenbach a. M., 138 pp., 1999a.

Gerstengarbe, F.-W., Werner, P. C., and Friedrich, K.: Applying non-hierarchical cluster analysis algorithms to climate classification: some problems and their solution, Theor. Appl. Climatol., 64, 143-150, 1999b.

Hains, J. C., Taubman, B. F., Thompson, A. M., Stehr, J. W., Marufu, L. T., Doddridge, B. G., and Dickerson, R. R.: Origins of chemical pollution derived from Mid-Atlantic aircraft profiles using a clustering technique, Atmos. Environ., 42, 1727-1741, 2008

Heintzenberg, J. and Charlson, R. J.: Editors, Clouds in the Perturbed Climate System Their Relationship to Energy Balance, Atmospheric Dynamics, and Precipitation, MIT Press, Cambridge, MA, 576 pp., 2009.

Hermann, M. and Wiedensohler, A.: Counting efficiency of condensation particle counters at low-pressures with illustrative data from the upper troposphere, J. Aerosol Sci., 32, 975-991, 2001.

Hermann, M., Heintzenberg, J., Wiedensohler, A., Brenninkmeijer, C. A. M., Heinrich, G., and Zahn, A.: Meridional distributions of aerosol particle number concentrations in the upper troposphere and lower stratosphere obtained by CARIBIC flights, J. Geophys. Res., 108, 4114, doi:10.1029/2001JD001077, 2003.

Hermann, M., Brenninkmeijer, C. A. M., Slemr, F., Heintzenberg, J., Martinsson, B. G., Schlager, H., van Velthoven, P. F. J., Wiedensohler, A., Zahn, A., and Ziereis, H.: Submicrometer aerosol particle distributions in the upper troposphere over the mid-latitude north Atlantic - results from the third route of CARIBIC, Tellus, 60(B), 106-117, 2008.

Hoor, P., Fischer, H., Lange, L., Lelieveld, J., and Brunner, D.: Seasonal variations of mixing layer in the lowermost stratosphere as identified by the $\mathrm{CO}-\mathrm{O}_{3}$ correlation form in situ measurements, J. Geophys. Res., 107, 4044, doi:10.1029/2000JD000289, 2002.

Hoor, P., Fischer, H., and Lelieveld, J.: Tropical an extratropical tropospheric air in the lowermost stratosphere over Europe: A CO-based budget, Geophys. Res. Lett., 32, L07802, doi:10.1029/2004GL022018, 2005.

IPCC, 2007: Climate Change 2007: Synthesis Report, Contribution of Working Groups I, II and III to the Fourth Assessment Report of the Intergovernmental Panel on Climate Change (Core Writing Team, edited by: Pachauri, R. K. and Reisinger, A.), IPCC, Geneva, Switzerland, 104 pp., 2007.

Kärcher, B.: Simulating gas-aerosol-cirrus interactions:
Process-oriented microphysical model and applications, Atmos. Chem. Phys., 3, 1645-1664, 2003, http://www.atmos-chem-phys.net/3/1645/2003/.

Kim, B.: http://www.faa.gov/about/office_org/headquarters_offices/ aep/models/sage/, last access: August 2009.

Kim, D., Wang, C., Ekman, A. M. L., Barth, M. C., and Rasch, P. J.: Distribution and direct radiative forcing of carbonaceous and sulfate aerosols in an interactive sizeresolving aerosol-climate model, J. Geophys. Res., 113, 16309, doi:10.1029/2007JD009756, 2008.

Korontzi, S., McCarty, J., Loboda, T., Kumar, S., and Justice, C.: Global distribution of agricultural fires in croplands from 3 years of Moderate Resolution Imaging Spectroradiometer (MODIS) data, Global Biogeochem. Cy., 20, GB2021, doi:10.1029/2005GB002529, 2006.

Krejci, R., Ström, J., de Reus, M., Hoor, P., Williams, J., Fischer, H., and Hansson, H.-C.: Evolution of aerosol properties over the rain forest in Surinam, South America, observed from aircraft during the LBA-CLAIRE 98 experiment, J. Geophys. Res., 108(D18), 4561, doi:10.1029/2001JD001375, 2003.

Kunz, A., Schiller, C., Rohrer, F., Smit, H. G. J., Nedelec, P., and Spelten, N.: Statistical analysis of water vapour and ozone in the UT/LS observed during SPURT and MOZAIC, Atmos. Chem. Phys., 8, 6603-6615, 2008,

http://www.atmos-chem-phys.net/8/6603/2008/.

Leyer, I. and Wesche, K.: Multivariate Statistik in der Ökologie, 1st edition, Springer, Berlin, 221 pp., 2007.

Liljequist G. H. and Cehak, K.: Allgemeine Meteorologie, 3rd edition, vieweg, Braunschweig/Wiesbaden, 412 pp., 1994.

Liu, D., Wang, Z., Liu, Z., Winker, D., and Trepte, C.: A height resolved global view of dust aerosols from the first year CALIPSO lidar measurements, J. Geophys. Res., 113, D16214, doi:10.1029/2007JD009776, 2008.

Lohmann, U. and Feichter, J.: Global indirect aerosol effects: a review, Atmos. Chem. Phys., 5, 715-737, 2005, http://www.atmos-chem-phys.net/5/715/2005/.

Malberg, H.: Meteorologie und Klimatologie: Eine Einführung, 3rd edition, Springer, Berlin, 354 pp., 1997.

Masuoka, E.: http://rapidfire.sci.gsfc.nasa.gov/firemaps/, last access: April 2009.

Minikin, A., Petzold, A., Ström, J., Krejci, R., Seifert, M., van Velthoven, P., Schlager, H., and Schumann, U.: Aircraft observations of the upper tropospheric fine particle aerosol in the northern and southern hemisphere at midlatitudes, Geophys. Res. Lett., 30(10), 1503, doi:10.1029/2002GL016458, 2003.

Müller, G.: http://www.wetterzentrale.de, last access: February 2008.

Nie, N. H.: http://www.spss.com, last access: February 2008.

Nguyen, H. N., Gudmundsson, A., and Martinsson, B. G.: Design and calibration of a multi-channel aerosol sampler for studies of the tropopause region from the CARIBIC platform, Aerosol Sci. Tech., 40, 649-655, 2006.

Nguyen, H. N. and Martinsson, B. G.: Analysis of C, N, and O in aerosol collected on an organic backing using internal blank measurements and variable beam size, Nucl. Instrum. Methods Phys. Res., Sect. B, 264, 96-109, doi:10.1016/j.nimb.2007.08.001, 2007.

Papaspiropoulos, G., Martinsson, B. G., Zahn, A., Brenninkmeijer, C. A. M., Hermann, M., Heintzenberg, J., Fischer, H., and 
van Velthoven, P. F. J.: Aerosol elemental concentrations in the tropopause region from intercontinental flights with the Civil Aircraft for Regular Investigation of the Atmosphere Based on an Instrument Container (CARIBIC) platform, J. Geophys. Res., 107(D23), 4671, doi:10.1029/2002JD002344, 2002.

Peylin, P., Bréon, F. M., Serrar, S., Tiwari, Y., Chédin, A., Gloor, M., Machida, T., Brenninkmeijer, C. A. M., Zahn, A., and Ciais, P.: Evaluation of Television Infrared observation Satellite (TIROSN) Operational Vertical Sounder (TOVS) spaceborne $\mathrm{O}_{2}$ estimates using model simulations and aircraft data, J. Geophys. Res., 112, D09313, doi:10.1029/2005JD007018, 2007.

Rossow, W. B.: http://isccp.giss.nasa.gov/products/browsed2.html, last access: April 2009.

Schröder, F., Kärcher, B., Fiebig, M., and Petzold, A.: Aerosol states in the free troposphere at northern midlatitudes, J. Geophys. Res., 107(21), 8126, doi:10.1029/2000JD000194, 2002.

Seinfeld, J. H. and Pandis, S. N.: Atmospheric Chemistry and Physics: From Air Pollution to Climate Change, 2nd edition, J. Wiley, New York, 1232 pp., 2006.

Singh, H. B., Anderson, B. E., Avery, M. A., Viezee, W., Chen, Y., Tabazadeh, A., Hamill, P., Pueschel, R., Fuelberg, H. E., and Hannan, J. R.: Global distribution and sources of volatile and nonvolatile aerosol in the remote troposphere, J. Geophys. Res., 107(11), 4121, doi:10.1029/2001JD000486, 2002.

Slemr, F., Ebinghaus, R., Brenninkmeijer, C. A. M., Hermann, M., Kock, H. H., Martinsson, B. G., Schuck, T., Sprung, D., van Velthoven, P., Zahn, A., and Ziereis, H.: Gaseous mercury distribution in the upper troposphere and lower stratosphere observed onboard the CARIBIC passenger aircraft, Atmos. Chem. Phys., 9, 1957-1969, 2009,

http://www.atmos-chem-phys.net/9/1957/2009/.

Søvde, O. A., Gauss, M., Isaksen, I. S. A., Pitari, G., and Marizy, C.: Aircraft pollution - a futuristic view, Atmos. Chem. Phys., 7, 3621-3632, 2007,

http://www.atmos-chem-phys.net/7/3621/2007/.

Taubman, B. F., Hains, J. C., Thompson, A. M., Marufu, L. T., Doddridge, B. G., Stehr, J. W., Piety, C. A., and Dickerson, R. R.: Aircraft vertical profiles of trace gas and aerosol pollution over the Mid-Atlantic United States: statistics and meteorological cluster analysis, J. Geophys. Res., 111(D10), D10S07, doi:10.1029/2005JD006196, 2006.
Textor, C., Schulz, M., Guibert, S., Kinne, S., Balkanski, Y., Bauer, S., Berntsen, T., Berglen, T., Boucher, O., Chin, M., Dentener, F., Diehl, T., Feichter, J., Fillmore, D., Ginoux, P., Gong, S., Grini, A., Hendricks, J., Horowitz, L., Huang, P., Isaksen, I. S. A., Iversen, T., Kloster, S., Koch, D., Kirkevåg, A., Kristjansson, J. E., Krol, M., Lauer, A., Lamarque, J. F., Liu, X., Montanaro, V., Myhre, G., Penner, J. E., Pitari, G., Reddy, M. S., Seland, Ø., Stier, P., Takemura, T., and Tie, X.: The effect of harmonized emissions on aerosol properties in global models - an AeroCom experiment, Atmos. Chem. Phys., 7, 4489-4501, 2007, http://www.atmos-chem-phys.net/7/4489/2007/.

Trepte, C. R.: http://www-calipso.larc.nasa.gov, last access: April 2009.

Weigelt, A., Hermann, M., van Velthoven, P. F. J., Brenninkmeijer, C. A. M., Schlaf, G., Zahn, A., and Wiedensohler, A.: Influence of clouds on aerosol particle number concentrations in the upper troposphere, J. Geophys. Res., 114, D01204, doi:10.1029/2008JD009805, 2009.

Williams, J., de Reus, M., Krejci, R., Fischer, H., and Ström, J.: Application of the variability-size relationship to atmospheric aerosol studies: estimating aerosol lifetimes and ages, Atmos. Chem. Phys., 2, 133-145, 2002, http://www.atmos-chem-phys.net/2/133/2002/.

Young, L.-H., Benson, D. R., Montanaro, W. M., Lee, S.-H., Pan, L. L., Rogers, D. C., Jensen, J., Stith, J. L., Davis, C. A., Campos, T. L., Bowman, K. P., Cooper, W. A., and Lait, L. R.: Enhanced new particle formation observed in the northern midlatitude tropopause region, J. Geophys. Res., 112, D10218, doi:10.1029/2006JD008109, 2007.

Zahn, A., Brenninkmeijer, C. A. M., Asman, W. A. H., Crutzen, P. J., Heinrich, G., Fischer, H., Cuijpers, J. W. M., and van Velthoven, P. F. J.: The budget of $\mathrm{O}_{3}$ and $\mathrm{CO}$ in the upper troposphere: The CARIBIC passenger aircraft results 1997-2001, J. Geophys. Res., 107(D17), 4337, doi:10.1029/2001JD001529, 2002.

Zahn, A. and Brenninkmeijer, C. A. M.: New Directions: A new tropopause defined, Atmos. Environ., 37, 439-440, 2003. 